\title{
CO ZBYLO Z ,NAPADENÝCH“ TRADIC? SPOLEK BÝVALÝCH HORSKÝCH MYSLIVCŮ A JEHO PÉČE O TRADIČNÍ VOJENSKÉ HODNOTY V SRN PO ZHROUCENÍ MÝTU O „ČISTÉM WEHRMACHTU“**
}

SOŇA MIKULOVÁ

\begin{abstract}
What Has Remained of the Traditions under Attack? The Association of Mountain Troops' Veterans and its Attitudes to Traditional Military Virtues in Germany after the Debunking of the Myth of the "Clean Wehrmacht"
\end{abstract}

This paper examines how the Kameradenkreis der Gebirgstruppe (Mountain Troops Association), one of the last significant German associations of World War II veterans, has dealt with the war crimes perpetrated by the Nazi Wehrmacht. It focuses on the reaction of the Kameradenkreis to a protest campaign organized by antifascist groups and various civic initiatives in Mittenwald, Bavaria, from 2002 to 2009. One of the main aims of the protesters was to disrupt traditional meetings of the former as well as active soldiers to commemorate fallen "comrades" at the Mountain Troops' Memorial near Mittenwald. The meetings were seen as a symbol of the surviving "tradition of perpetrators." The study analyzes how the leaders of the Kameradenkreis have changed their attitudes towards the Wehrmacht war crimes. Keywords: Germany; military traditions; veteran culture; antifascist movements; war crimes; wehrmacht; mountain troops association

DOI: $10.14712 / 23363231.2015 .76$

\section{Úvod}

Veteránská kultura spolků bývalých př́slušníků wehrmachtu ve Spolkové republice Německo zažívala období svého největšího rozkvětu od padesátých do

* Článek vznikl v rámci Specifického vysokoškolského výzkumu UK v Praze, projekt č. 260114/2014. 
konce sedmdesátých let minulého století. ${ }^{1} \mathrm{Na}$ základě publikačních a jiných aktivit veteránů si většinová společnost osvojila interpretaci, podle které německá armáda vedla „normálni“ válku, jež neměla nic společného s nacistickými zvěrstvy. Veteránské organizace tak v nemalé míře přispěly ke všeobecnému souhlasu západoněmecké veřejnosti s vybudováním Bundeswehru v druhé polovině padesátých let. Hegemoniální postavení v rámci veřejného vzpomínání na druhou světovou válku si tyto spolky dlouhodobě udržovaly i přesto, že všechny dohromady sdružovaly jen velmi malou část populace. ${ }^{2}$ Od osmdesátých let sice jejich společenské postavení sláblo a s ním i vliv na vzpomínkový diskurs, nicméně jimi zastávaná legenda o „čistém wehrmachtu" nadále dominovala v povědomí velké většiny společnosti až do poloviny devadesátých let minulého století.

Teprve v roce 1995, kdy byla zahájena první putovní výstava o válečných zločinech německých vojáků, definitivně padl celospolečenský konsensus připisující všechny zločiny proti lidskosti a válečné zločiny pouze nacistům a jednotkám SS. Bouřlivé a dlouhotrvající diskuse německé veřejnosti, které tato výstava vyvolala, přispěly ke zvýšení povědomí o agresivitě německého vedení války, zdaleka však neobjasnily všechny sporné otázky. I v následujících dvou desetiletích tak v německé společnosti zůstávalo téma válečných zločinů wehrmachtu citlivé, tím spíš, že v ní nadále působily skupiny bránící dobrou pověst wehrmachtu, v prvé řadě veteránské spolky.

Dosavadní bádání německých historiků k veteránské kultuře a vlivu veteránských spolků na poválečnou kulturu vzpomínání ve Spolkové republice Německo se soustředí především na její počátky, př́padně na dobu do poloviny devadesátých let minulého století. ${ }^{3}$ Předkládaná studie využívá závěrů těchto prací k vytvoření obecného rámce pro zkoumání vývoje a činnosti jedné konkrétní veteránské organizace, a sice Kameradenkreis der Gebirgstruppe (dále jen Kameradenkreis).

1 K typickým znakům veteránské kultury patřily podle Thomase Kühneho vzpomínání na společné válečné zážitky, ritualizovaný kult mrtvých a mýtus „,kamarádstvi“, přednášky a diskuse se zástupci politických stran či Bundeswehru, vzájemná podpora mezi členy včetně finanční výpomoci veteránům ve zvlášt tíživé situaci a nabídka volnočasových aktivit pro celé rodiny. Viz Thomas Kühne, „Zwischen Vernichtungskrieg und Freizeitgesellschaft: Die Veteranenkultur der Bundesrepublik (1945-1995)“, in Nachkrieg in Deutschland, ed. Klaus Naumann (Hamburg: Hamburger Edition, 2001), 90-113, zde 94.

2 Jörg Echternkamp, „Arbeit am Mythos: Soldatengenerationen der Wehrmacht im Urteil der westund ostdeutschen Nachkriegsgesellschaft", in Nachkrieg in Deutschland, ed. Klaus Naumann (Hamburg: Hamburger Edition, 2001), 421-43, zde 431.

3 Kühne, „Zwischen Vernichtungskrieg und Freizeitgesellschaft“, 90-113; Jörg Echternkamp, „Mit dem Krieg seinen Frieden schließen - Wehrmacht und Weltkrieg in der Veteranenkultur 1945-1960“, in Von der Kriegskultur zur Friedenskultur? Zum Mentalitätswandel in Deutschland seit 1945, ed. Thomas Kühne (Münster: Lit, 2000), 78-93. 
Na rozdíl od nich však sleduje postoj této organizace $\mathrm{k}$ otázce válečných zločinů a k mýtu o „čistém wehrmachtu“ i v posledních dvou dekádách. Snaží se tak přispět k bádání o veteránské kultuře po roce 1995, aniž by si činila nárok na její vyčerpávající zmapování. Zároveň text zkoumá postoje tohoto veteránského spolku coby nositelů specifických vzpomínek na roli wehrmachtu za války v reakci na aktivity svých oponentů z občanské společnosti. Tím se dotýká širšího tématu kolektivního vzpomínání na druhou světovou válku ve Spolkové republice Německo z málo známé perspektivy zástupců menšinového názoru v celospolečenské diskusi. $^{4}$

Kameradenkreis, původně Kameradenkreis ehemaliger deutscher Gebirgssoldaten (Kruh kamarádů bývalých německých horských vojáků), ${ }^{5}$ vznikl jako zastřešující organizace pro všechny skupiny, které sdružovaly bývalé příslušníky všech horských divizí wehrmachtu ze Západního Německa, ale i z Rakouska a severní Itálie (původně Jižního Tyrolska, dnes autonomní oblasti Tridentsko-Horní Adiže). ${ }^{6}$ Nepatř̌il sice $\mathrm{k}$ nejpočetnějším veteránským spolkům, ale po celé poválečné období mezi nimi zaujímal významnou pozici díky tradiční prestiži horských myslivců. ${ }^{7} \mathrm{~V}$ posledních dvaceti letech se řadil $\mathrm{k}$ těm nejvýznamnějším, protože byl jedním z mála spolků, který díky rekrutování nových členů nezanikl na základě jejich přirozeného úbytku, a protože se nadále snažil prosazovat své cíle jak mezi vojáky Bundeswehru, tak na veřejnosti, i když už spíše jen v lokálním měřítku. $S$ tím souvisel i další důvod, proč byl pro účely této studie vybrán Kameradenkreis. V letech 2002 až 2009 se stal terčem pravděpodobně nejvýraznějších a nejintenzivnějších protestů, které občanské iniciativy v poválečném Německu vedly proti konkrétní veteránské organizaci. ${ }^{8} \mathrm{Z}$ důvodů, které budou přiblíženy dále v textu, se

4 Obecně např. Jörg Echternkamp a Stefan Martens, eds., Der Zweite Weltkrieg in Europa: Erfahrung und Erinnerung (Paderborn: Schöningh, 2007). Srov. také Harald Welzer, který zkoumal válečné vzpomínky veteránů $\mathrm{v}$ rámci kolektivní paměti rodinných příslušníků, in Harald Welzer, Sabine Moller a Karoline Tschuggnall, „Opa war kein Nazi“: Nationalsozialismus und Holocaust im Familiengedächtnis (Frankfurt/Main: Fischer-Taschenbuch-Verl., 2002).

5 V roce 1958 si spolek změnil název na Kameradenkreis der ehemaligen Gebirgstruppe (Kruh kamarádů bývalých horských jednotek) a od roku 1982, kdy se otevřel vojákům Bundeswehru, jejich rodinám a pozůstalým, se nazývá Kameradenkreis der Gebirgstruppe (Kruh kamarádů horských jednotek).

6 První Kameradschaft bývalých horských myslivců vznikl v Rakousku stejně jako v severní Itálii už $\mathrm{v}$ druhé polovině 50. let. Bývalí př́slušníci horských divizí, kteří se po válce stali občany NDR, se mohli stát členy Kameradenkreisu až od roku 1990.

7 Jednotky horských myslivců byly a stále jsou elitními oddíly německé armády, které se vyznačovaly velkou výkonností, odolností proti extrémním geografickým a klimatickým podmínkám a v neposlední řadě vysokým stupněm disciplíny a vzájemné soudržnosti.

8 Hans Lindinger, „Ein Appell an die Medien. Gedanken eines besorgten Demokraten anlässlich der Brendtenfeier 2005“, Die Gebirgstruppe 54, č. 3 (2005): 11-12. 
v Mittenwaldu a bezprostředním okolí v tomto období konala jedna malá a sedm velkých manifestací a protestních akcí namířených mimo jiné proti cílům a samotné podstatě tohoto spolku.

Iniciátorem a hlavním organizátorem protestů po celou dobu jejich trvání byla Pracovní skupina Napadnutelná péče o tradice (Arbeitskreis - zkráceně AK - Angreifbare Traditionspflege).${ }^{9}$ Jednalo se volné sdružení několika jednotlivců z celého Německa bez tradiční spolkové struktury, založené právě za účelem pořádání protestních akcí proti Kameradenkreisu. $V$ průběhu kampaně se $\mathrm{k}$ němu přidávaly další osoby, prrípadně ho zase opouštěly. Jejich přesné počty pracovní skupina záměrně nezveřejňovala. Již koncem roku 2002 se na společné organizaci mittenwaldské kampaně začalo podílet krajně levicové Sdružení pronásledovaných nacismem a Spolek antifašistek a antifašistů (Vereinigung der Verfolgten des Naziregimes - Bund der Antifaschistinnen und Antifaschisten, VVN-BdA). ${ }^{10}$ $\mathrm{V}$ dalších letech se $\mathrm{k}$ organizátorům přidávaly další občanské iniciativy jako Pracovní skupina Distomo $(A K \text { Distomo })^{11}$ a jednotlivci z Německa, Rakouska, Itálie a ̌̌ecka.

Kromě skupiny Napadnutelná péče o tradice sledovaly tyto organizace a skupiny primárně různé specifické cíle, které nesouvisely př́mo s činností Kameradenkreisu, proto také ve stejném období probíhala jejich další setkání a happeningy v Mnichově a jiných místech Německa. Tato studie se však s ohledem na výzkumnou otázku zabývala pouze protestními akcemi v Mittenwaldu pořádanými pod heslem „Napadnutelná péče o tradice“, a především pak reakcí Kameradenkreisu

\footnotetext{
${ }^{9}$ Název vysílal jasný politický signál vůči bavorské Křestanskosociální unii (CSU), potažmo celému konzervativnímu táboru. Reagoval na projev bavorského premiéra, předsedy CSU a člena Kameradenkreisu Edmunda Stoibera při slavnostním rozloučení s 1. horskou divizí Bundeswehru v červenci 2001, ve kterém hovořil o „nenapadnutelné péči o tradice“ horských myslivců. Viz „Ansprache des Bayerischen Ministerpräsidenten Dr. Edmund Stoiber“, Die Gebirgstruppe 50, č. 4 (2001): 10-13, zde 11.

10 Vereinigung der Verfolgten des Naziregimes - Bund der Antifaschistinnen und Antifaschisten, oficiální stránky: http://www.vvn-bda.de/. Původní sdružení, založené roku 1947 v Berlíně, se skládalo pouze z obětí nacismu pronásledovaných z politicko-ideologických důvodů. V roce 1953 byla organizace v NDR nahrazena Výborem antifašistických bojovníků, zatímco západoněmecká organizace dál fungovala i díky finanční podpoře NDR. Od roku 1971 se rozšírila o mladou generaci antifašistů (BdA). Od roku 2002 sdružuje VVN-BdA jak bývalou západní, tak východní organizaci, jakož i další sdružení ve společném boji proti fašismu v duchu ortodoxní komunistické ideologie. Její členy tvoří bývalí členové Německé komunistické strany (DKP), respektive strany Levice (Die Linke), ale i nezávislí levicově orientovaní aktivisté.

11 Oficiální stránky iniciativy viz AK-Distomo, http://www.nadir.org/nadir/initiativ/ak-distomo/. Pracovní skupina odvozuje svoje počátky od účasti na oficiální připomínkové akci k 60 . výročí od vyvraždění 218 obyvatel Distoma bez ohledu na jejich věk a pohlaví jednotkami SS v roce 1944. Jejím cílem je podpořit nároky pozůstalých obětí na odškodnění od německé vlády.
} 
na ni. Klíčová otázka přitom zněla, zda a jakým způsobem vůdčí členové veteránského spolku v důsledku této kampaně přehodnotili tradičně zastávaný pohled na působení bývalých horských myslivců za druhé světové války a na válečné zločiny, na kterých se zčásti podíleli.

Studie se dělí do tří tematicko-chronologických částí a závěru. První část představuje exkurs do historie Kameradenkreisu od jeho založení v roce 1951 do roku 2002. Čtenář je v něm uveden do širší problematiky aktivit spolku v rámci veteránské kultury $\mathrm{v}$ západním a sjednoceném Německu a jeho oponentů z řad občanské společnosti. $V$ druhé části jsou stručně nastíněny hlavní cíle protestujících a průběh mittenwaldské kampaně ve sledovaném období. Vlastní předmět zkoumání je pak obsahem třetí části, která analyzuje praxi vzpomínkových setkání veteránů na Hohe Brendten v letech 2002 až 2013 a zároveň reakce předsednictva a členů Kameradenkreisu na protestní kampaň jak uvnitř spolku, tak směrem $\mathrm{k}$ veřejnosti. Sledované období záměrně přesahuje rok, kdy byla kampaň oficiálně skončena, tak aby bylo možno posoudit, zda př́padné změny $\mathrm{v}$ interpretaci a způsobu vzpomínání na válečnou minulost ze strany Kameradenkreisu byly jen dočasného charakteru s ohledem na tlak protestujících, nebo jestli signalizují nový dlouhodobý trend. Zvláštní pozornost je věnována veřejnému postoji představitelů Kameradenkreisu k masakru řeckých civilistů v obci Kommenu ${ }^{12}$ a italských zajatců na Kefalonii. ${ }^{13}$ Aktivisté oba tyto válečné zločiny tematizovali už od začátku kampaně a požadovali odsouzení pachatelů.

Změny v nahlížení na chování horských myslivců za druhé světové války se mohly odrážet téměř ve všech verbálních či psaných projevech a aktivitách členů Kameradenkreisu. S ohledem na zaměření a omezený rozsah studie bylo však nutné soustředit se jen na ty, které měly přímou či nepřímou souvislost s požadavky a kritikou protestujících v rámci jednotlivých ročníků mittenwaldské kampaně. Hlavním zdrojem byly články z dvouměsíčníku Die Gebirgstruppe, určeného v prvé řadě členům spolku. Šlo především o projevy předsedů spolku přednesené

12 V srpnu 1943 zastřelila či jiným brutálním způsobem usmrtila jednotka 1. horské divize 317 mužů, žen a dětí, obyvatel obce Kommeno. Obec byla zároveň vypleněna a vypálena v rámci odvetného opatření za neprokázanou spolupráci s partyzány. Srov. Stefan Stracke, „Mörder unterm Edelweiß Kriegsverbrechen der Gebirgsjäger", in Mörder unterm Edelweiß: Dokumentation des Hearings zu den Kriegsverbrechen der Gebirgsjäger, ed. Ralph Klein, Regina Mentner a Stephan Stracke (Köln: Papyrossa Verlag, 2004), 44-49.

13 Divize Acqui na ostrově Kefalonia čítající asi 11500 mužů odmítla po vyhlášení příměří, které Itálie uzavřela se spojenci, složit zbraně a vedla s německými vojáky krátký boj. Po jeho konci bylo podle stř́zilivých odhadů novějších historických prací 2000 až 4000 italských vojáků a důstojníků (podle materiálů protestujících 4000 až 5000) protiprávně zastřeleno na základě rozkazu Hitlera. Srov. Stracke, „Mörder unterm Edelweiß“, 55-57. 
u př́ležitosti výročních setkání na Hohe Brendten, svědectví, vzpomínky k vybraným válečným zločinům a komentáře dalších členů předsednictva $\mathrm{k}$ protestní kampani. Na rozdíl od oficiálních internetových stránek ${ }^{14}$ je toto periodikum skutečnou komunikační platformou uvnitř spolku. V prŕpadě protestujících byly jejich cíle, požadavky a způsob jejich protestu popsány na základě jejich vlastních prohlášení a hodnocení akcí, dostupných na několika internetových stránkách pracovní skupiny Napadnutelná péče o tradice (AK Angreifbare Traditionspflege), ${ }^{15}$ př́ípadně formou tištěných materiálů jako jsou letáky, brožury a plakáty. Rovněž internetové stránky VVN-BdA obsahují archiv s dobovými výzvami a zprávami k jednotlivým protestním akcím, včetně novinových článků, dopisů adresovaných politikům, a další informace. ${ }^{16}$ Od systematického zkoumání mediálního obrazu kampaně bylo s ohledem na klíčovou otázku studie upuštěno. Zvláštní pozornost byla věnována pouze vyjádřením, která pronesli v reakci na protestní akce zástupci Kameradenkreisu a která byla otištěna převážně v regionálních médiích v letech 2002 až $2010 .{ }^{17}$

Této kampani a reakcím Kameradenkreisu v letech 2002 až 2005 se dosud věnovala jediná odborná práce, pocházející z pera Jennifer Gronau, která z politologického hlediska analyzuje mediální diskurs o vzpomínkových setkáních na Hohe Brendten. Svou původně diplomovou práci chápe Gronau rovněž jako př́íspěvek k aktivitám organizátorů kampaně v Mittenwaldu. ${ }^{18} \mathrm{Na}$ historický vývoj Kameradenkreisu a jeho péči o tradice se v kratších článcích zaměřilo několik historiků a publicistů, kteří se také více či méně angažovali v pracovní skupině

${ }^{14}$ Kameradenkreis der Gebirgstruppe E.V., http://www.kamkreis-gebirgstruppe.de/.

15 Oficiálních stránek AK Angreifbare Traditionspflege, na kterých byly zveřejňovány výzvy ke kampaním a prohlášení pro média, bylo několik: http://www.nadir.org/nadir/kampagnen/mittenwald (pro kampaně do roku 2007) a http://mittenwald.blogsport.de/ (kampaně 2007-2008). Stránky vytvořené pro rok 2009, http://www.keine-ruhe.org/Mittenwald, které obsahovaly téměř všechny do té doby zveřejňované texty organizátorů kampaně, historické podklady $\mathrm{k}$ jednotlivým válečným zločinům a mediální ohlasy na internetu, již nejsou dostupné.

16 Vereinigung der Verfolgten des Naziregimes - Bund der Antifaschistinnen und Antifaschisten, Landesvereinigung NRW, Archiv, http://www.nrw.vvn-bda.de/archiv.htm. Tiskem vyšla dokumentace prohlášení spolkového mluvčího VVN-BdA Ulricha Sandera, kopie jeho korespondence a dobových novinových článků související s mittenwaldskou kampaní a dlouholetými aktivními protesty VVN-BdA proti péči o tradice horských myslivců Kameradenkreisu, které nezř́dka vyústily v soudní spor. Viz Bundesausschuss der VVN-BdA, ed., Eine Mordstruppe. Zur Auseinandersetzung zwischen dem völkisch-militaristischen Kameradenkreis Gebirgstruppe und der VVN - Bund der Antifaschisten (Renchen: druckwerkstatt renchen, 2009).

17 Zejména Garmisch-Partenkirchner Tagblatt, Münchner Merkur, Frankfurter Rundschau a další.

${ }^{18}$ Jennifer Gronau, Auf blinde Flecken zeigen: Eine Diskursanalyse soldatischer Gedenkpraktiken und Möglichkeiten des Widerspruchs am Beispiel der Gebirgsjäger in Mittenwald (Oldenburg: BIS-Verl. der Carl-von-Ossietzky-Univ., 2009), elektronicky http://oops.uni-oldenburg.de/896/1/groauf09.pdf. 
Napadnutelná péče o tradice či VVN-BdA. ${ }^{19}$ Jejich poznatky a argumentace se proto překrývají se stanovisky protestujících šířených během kampaně. Nejkomplexnější pohled přináší sborník Mörder unterm Edelweiß pod redakcí Ralpha Kleina, Reginy Mentner a Stephana Strackeho. ${ }^{20}$ Úvodní kapitoly přinášejí souhrnný pohled na chápání tradic Kameradenkreisu, na motivy a cíle protestní iniciativy pracovní skupiny Napadnutelná péče o tradice v letech 2002 a 2003 a vylíčení některých válečných zločinů horských myslivců v Řecku. Zbytek sborníku je tvořen svědeckými výpověd’mi řeckých, italských i německých pamětníků válečných událostí, zaznamenaných během manifestace v Mittenwaldu $\mathrm{v}$ roce 2003.

K péči o tradice wehrmachtu obecně existuje řada odborných studií německé i zahraniční provenience. Většina se přitom soustředí na to, jak tyto tradice byly a jsou chápány uvnitř Bundeswehru. ${ }^{21}$ Širším kontextem válečné historie horských divizí wehrmachtu a jejich podílu na válečných zločinech včetně Kefalonie a Kommena a částečně i jejich poválečným zpracováním ze strany veteránů a německé justice se zabývají nedávné práce Hermanna Franka Meyera. ${ }^{22} \mathrm{Ze}$

19 AK Angreifbare Traditionspflege, „Der ,Kameradenkreis der Gebirgstruppe“, in Friede, Freude, deutscher Eintopf: Rechte Mythen, NS-Verharmlosung und antifaschistischer Protest, ed. Arbeitskreis gegen den kärntner Konsens (Wien: mandelbaum kritik \& utopie, 2011), 145-59; Markus Mohr, „Von Eduard Dietl bis zu Donald Rumsfeld. Zur Geschichte der Gebirgsjäger und ihres Kameradenkreises in der Bundesrepublik", analyse \& kritik, č. 505 (2006): 26-27; Ulrich Sander, „Mörderische Traditionspflege: Ermittlungen gegen Gebirgstruppe der Wehrmacht”, Der rechte Rand, č. 80 (2003): 19.

20 Ralph Klein, Regina Mentner a Stephan Stracke, ed., Mörder unterm Edelweiß: Dokumentation des Hearings zu den Kriegsverbrechen der Gebirgsjäger (Köln: Papyrossa Verlag, 2004). K bilanci a významu protestní kampaně z pohledu jejích iniciátorů srov. také Ralph Klein, Regina Mentner a Stephan Stracke, „,Dokumentation und Aktion' - Möglichkeiten geschichtspolitischer Intervention am Beispiel der Traditionspflege deutscher Gebirgsjäger", in Kritische Geschichte: Perspektiven und Positionen, ed. Richard Heigl, Petra Ziegler a Philip Bauer (Leipzig: Leipziger Universitätsverlag, 2005), 193-212.

${ }^{21}$ Loretana de Libero, Tradition in Zeiten der Transformation: zum Traditionsverständnis der Bundeswehr im frühen 21. Jahrhundert (Paderborn: F. Schöningh, 2006); John Zimmermann, „Vom Umgang mit der Vergangenheit. Zur historischen Bildung und Traditionspflege in der Bundeswehr", in Die Bundeswehr 1955 bis 2005: Rückblenden, Einsichten, Perspektiven, ed. Frank Nägler (München: Oldenbourg, 2005), 115-29; Jakob Knab, Falsche Glorie: Das Traditionsverständnis der Bundeswehr (Berlin: Links, 1995); Donald Abenheim, Bundeswehr und Tradition. Die Suche nach dem gültigen Erbe des deutschen Soldaten (München: Oldenbourg, 1989).

22 Hermann Frank Meyer, Blutiges Edelweiß: Die 1. Gebirgs-Division im Zweiten Weltkrieg (Berlin: Links, 2008); Hermann Frank Meyer, Kommeno. Erzählende Rekonstruktion eines Wehrmachtsverbrechens in Griechenland (Köln: Romiosini, 1999). K poválečnému zacházení se vzpomínkou na masakr na Kefalonii viz také Christoph U. Schminck-Gustavus, Kephalloniá, 1943-2003: auf den Spuren eines Kriegsverbrechens (Bremen: Donat, 2004). Srov. Soňa Mikulová, „Př́ípad Kefalonia ve stínu legendy o „čistém“ wehrmachtu“, Střed. Časopis pro mezioborová studia Strední Evropy 19. a 20. století 3, č. 1 (2012): 80-118. 
starších prací k obsazení Řecka a Itálie a válečným zločinům na civilním obyvatelstvu je třeba vyzdvihnout studie Hagena Fleischera a Gerharda Schreibera. ${ }^{23}$ Pod používaným termínem válečný zločin je myšleno porušení mezinárodního válečného práva a mezinárodních smluv jako Haagské úmluvy, platných už během druhé světové války, tak jak je definoval poválečný norimberský tribunál. Jednalo se především o vraždění, mučení a zavlečení válečných zajatců a civilního obyvatelstva okupovaných oblastí do pracovních či koncentračních táborů a excesivní zabíjení civilistů coby rukojmí v rámci odvetných opatření v boji proti partyzánům. ${ }^{24}$

\section{Kameradenkreis a jeho péče o tradice v kontextu veteránské kultury}

Začátky veteránských organizací ve Spolkové republice Německo nebyly jednoduché. $\mathrm{V}$ době bezprostředně po válce panovala $\mathrm{v}$ psychicky a materiálně zdevastované zemi všeobecná únava a vyčerpání z prohrané války a jejích následků. Heroizace válečného tažení či jeho protagonistů v té době nepřipadala $\mathrm{v}$ úvahu. Naopak, vítěznými mocnostmi prosazená demilitarizace a potrestání hlavních viníků nacistických a válečných zločinců se zprvu setkávala se souhlasem většiny obyvatelstva. Díky zprávám ze soudních líčení v norimberských procesech s nejvyššími představiteli vrchního velení a nejvyššími generály byla německá veřejnost již tehdy podrobně informována o obrovském rozsahu válečných zločinů nejen na východní frontě, ale i na Balkáně. Vojáci, kteří se postupně vraceli z bojišţ a západních zajateckých táborů, se tak během své integrace do civilní společnosti museli vyrovnávat nejen se svými válečnými traumaty, ale i veřejnou stigmatizací. ${ }^{25}$

To druhé však již neplatilo o bývalých zajatcích v Sovětském svazu, jejichž návrat $\mathrm{v}$ první polovině padesátých let byl vítán $\mathrm{s}$ všeobecným nadšením. Mezitím se totiž změnila nálada obyvatel západních okupačních zón vůči denacifikaci

${ }^{23}$ Hagen Fleischer, Im Kreuzschatten der Mächte - Griechenland 1941-1944: Okkupation - Resistanz Kolaboration (Frankfurt am Main: Peter Lang Verlag, 1986); Gerhard Schreiber, Deutsche Kriegsverbrechen in Italien. Täter - Opfer - Strafverfolgung (München: Beck, 1996). Viz také jednotlivé prŕspěvky v práci Gerd R. Ueberschär, ed., Orte des Grauens (Darmstadt: Primus, 2003); Wolfram Wette a Gerd R. Ueberschär, eds., Kriegsverbrechen im 20. Jahrhundert (Darmstadt: Wissenschaftliche Buchgesellschaft, 2001); Loukia Droulia a Hagen Fleischer, eds., Von Lidice nach Kalavryta: Widerstand und Besatzungsterror (Berlin: Metropol, 1999).

${ }^{24}$ Martin Zöller und Kazimierz Leszcyński, Fall 7. Das Urteil im Geiselmordprozess, gefällt am 19. Februar 1948 vom Militärgerichtshof $V$ der Vereinigten Staaten von Amerika (Berlin: Deutscher Verlag der Wissenschaften, 1965), 13.

25 Jörg Echternkamp, „Wut auf die Wehrmacht? Vom Bild der deutschen Soldaten in der unmittelbaren Nachkriegszeit“" in Die Wehrmacht: Mythos und Realität, ed. Rolf-Dieter Müller a Hans Erich Volkmann (München: Oldenbourg, 1999), 1058-80. 
a trestání válečných zločinců, stejně jako politika západních spojenců v těchto otázkách. Začátek studené války umocnil zájem západních spojenců na znovuvyzbrojení nově vzniklé Spolkové republiky Německo. Toho využily vojenské elity wehrmachtu a prostřednictvím Adenauerovy vlády dosáhly předčasného propuštění všech německých generálů odsouzených soudy západních spojenců. ${ }^{26}$

Postupná rehabilitace a integrace bývalých příslušníků wehrmachtu do společnosti se dařily i díky veřejným prohlášením vrchního velitele NATO Dwighta D. Eisenhowera a spolkového kancléře Konrada Adenauera o čestném a statečném boji většiny německých vojáků z první poloviny padesátých let. ${ }^{27}$ Ve svém úsilí získat veřejné mínění i pro myšlenku znovuvyzbrojení však konzervativní vlády Adenauera zpočátku narážely na odpor širokého mírového hnutí Beze mne (Ohne-mich-Bewegung). Při paměti válečných hrůz a utrpení, v neposlední řadě i s ohledem na plány SSSR sjednotit oba německé státy pod podmínkou neutrality, se v něm počátkem 50. let spojilo několik občanských sdružení, politických uskupení, odborových organizací a jednotlivců, včetně mnoha bývalých vojáků, aby svými protesty varovali před novou militarizací Západního Německa. ${ }^{28}$

Naproti tomu tradiční spolky veteránů (Traditionsverbände), které si jako hlavní cíl kladly očištění jména německého vojáka, uchování „slavných vojenských tradic", jakož i podporu obranyschopnosti nového demokratického státu, působily jako společenský aktér přesně v duchu vládní politiky znovuvyzbrojení. Není proto divu, že už od počátku se jejich velkých setkání účastnili významní představitelé státu či místní honorace, kteří jim tak vyjadřovali symbolickou podporu. Uznáním společenského významu umírněných veteránských spolků a jistou finanční podporou Adenauerovy vlády navíc bránily nárůstu krajně pravicových, revisionistických skupin ve společnosti. ${ }^{29}$

Kameradenkreis se coby zastřešující organizace příslušníků všech bývalých horských divizí Německé říše oficiálně ustavil v prosinci $1951 .{ }^{30}$ Hlavním motivem

${ }^{26}$ Více viz Norbert Frei, Vergangenheitspolitik: Die Anfänge der Bundesrepublik und die NS-Vergangenheit (München: Beck, 1997), 133-306.

27 Wolfram Wette, Wehrmacht. Obrazy neprítele, vyhlazovací válka a legendy (Praha: Argo, 2006), 208-9.

28 Andreas Buro, „Friedensbewegung“, in Die sozialen Bewegungen in Deutschland seit 1945: Ein Handbuch, ed. Roland Roth a Dieter Rucht (Frankfurt, New York: Campus, 2008), 267-91, zde 272.

29 Vzhledem k tomu, že ze všech veteránských spolků tvořily ty radikálně orientované jen minimální počet, je patrno, že se tento cíl podařilo naplnit. Viz Alaric Searle, „Veterans’ Associations and Political Radicalism in West Germany 1951-54: A Case Study of the Traditionsgemeinschaft Grossdeutschland“, Canadian Journal of History 8 (1999): 221-48, zde 223.

${ }^{30}$ August Wittmann, „Sinn und Ziel unserer Kameradschaft, Weihnachts-Mitteilungen der ehemaligen deutschen Gebirgstruppen, 1952, 12-14. 
veškerých aktivit bylo „kamarádstvi“ ve vojenském smyslu slova. ${ }^{31}$ Soudržnost a solidarita s podřízenými i s nadřízenými byly jednou $\mathrm{z}$ tradičních vojenských ctností, které vyzdvihovaly všechny tradiční veteránské spolky, ale pro bývalé horské myslivce znamenaly jednu z nejdůležitějších. Svědčí o tom nejen název spolku - Kruh kamarádů bývalých horských vojáků, ale i vyjádření předních členů Kameradenkreisu. Ti poukazovali na to, že jim „kamarádstvi“ pomáhalo přežít v extrémně obtížných geografických a klimatických podmínkách, ve kterých horští myslivci bojovali. Zároveň díky němu překonali léta „hanby“ bezprostředně po válce, kdy němečtí důstojníci a vojáci byli podle členů Kameradenkreisu „neprávem“ souzeni za válečné zločiny nebo drženi v zajateckých táborech. ${ }^{32}$

Založením Kameradenkreisu se jeho členové zavazovali k utužování vztahů mezi „kamarády“ v mírové době. Motivovalo je, aby pomáhali válečným invalidům a rodinám padlých, zprostředkovávali si zaměstnání a byli si vzájemně oporou. Z „kamarádství také vzpomínali na padlé spolubojovníky a aktivně bránili jejich památku a čest proti „nactiutrhačným“ kampaním. Mezi aktivity členů proto patřily společné vzpomínkové akty, stavění pomníků, péče o vojenské hřbitovy v zahraničí, ale i sdílení informací o nezvěstných vojácích, výzvy ke generální amnestii a petice za propuštění odsouzených př́slušníků wehrmachtu či válečných zajatců. Jako důležitý komunikační a informační prostř̌edek sloužil členům Kameradenkreisu dvouměsíčník Die Gebirgstruppe, který vytvářel „kamarádské“ pouto mezi jednotlivými členy a místními organizacemi v době, kdy se nekonala setkání. ${ }^{33}$

Kameradenkreis se také od začátku snažil o upevnění vztahů s civilním obyvatelstvem tím, že se delegace jeho členů účastnila tradičních lidových slavností v Mittenwaldu a na jiných místech. Zároveň byla veřejnost zvána $\mathrm{k}$ účasti na každoročních setkáních bývalých horských myslivců, jimiž si připomínaly padlé „kamarády“. Když byl krátce po založení spolku vztyčen na Hohe Brendten u Mittenwaldu centrální pomník, ${ }^{34}$ označil to tehdejší předseda spolku za důkaz

31 Více k fenoménu „kamarádstvi“ mezi bývalými př́islušníky wehrmachtu viz Thomas Kühne, Kameradschaft: die Soldaten des nationalsozialistischen Krieges und das 20. Jahrhundert (Göttingen: Vandenhoeck \& Ruprecht, 2006).

32 August Wittmann, „4 Jahre Kameradenkreis der Gebirgstruppe, Rückschau und Vorschau“, Die Gebirgstruppe 4, Sonderdruck, č. 6 (1955): 4-8, zde 3.

33 Zpočátku nepravidelný zpravodaj vycházel péćí zakladatele a prvního předsedy Kameradenkreisu Rudolfa Konrada od roku 1952. Od roku 1954 dodnes vychází pravidelně pod názvem Die Gebirgstruppe.

${ }^{34}$ Památník tvoří téměř deset metrů vysoký dřevěný křriž vztyčený před dvěma třináctimetrovými sloupy z kamene a betonu. Na nich byly vytesány pouze data začátku a konce první a druhé světové války spolu s odkazem na ty, kdo nechal památník zhotovit. Blíže viz Paul Bauer, „Der Bau des Denkmals“, Die Gebirgstruppe 6, č. 2-4 (1957): 255-66. 
„Znovuobnovení spojení mezi vojákem a obyvatelstvem, které bylo po válce porušeno“. ${ }^{35}$ Už při položení základního kamene v roce 1956 přišlo asi 30000 lidí, veteránů, jejich rodinných př́slušníků a přátel v čele s představiteli místního politického, společenského a kulturního života. Stejně vysoký počet členů i nečlenů spolku se účastnilo i jeho vysvěcení o rok později. Od té doby se slavnostní setkání k uctění památky padlých na Hohe Brendten konalo vždy na církevní svátek letnic a v prvních desetiletích přicházelo každý rok několik tisíc návštěvníků z blízkého i vzdáleného okolí. ${ }^{36}$

Nejvyšším nemateriálním cílem Kameradenkreisu stejně jako dalších veteránských spolků v době založení bylo obnovit ve Spolkové republice prestiž vojenského povolání a předávat budoucím generacím vojenské ctnosti jako věrnost, statečnost a oddanost. ${ }^{37}$ Ty byly podle bývalých horských myslivců stejně důležité $\mathrm{v}$ době války jako $\mathrm{v}$ době míru právě proto, že jej pomáhaly udržovat. Potřebu obranyschopnosti německé demokracie, $\mathrm{k}$ jejíž podpoře a budování se členové spolku zavázali, zdůrazňoval Kameradenkreis poukazem na nebezpečí ze strany Sovětského svazu. ${ }^{38}$ Společně s dalšími veteránskými organizacemi proto podporoval myšlenku branné povinnosti a vzniku nových ozbrojených sil.

Se vstupem Spolkové republiky do NATO a založením Bundeswehru v roce 1955 skončila historická etapa hnutí Beze mne. I když mírové a antimilitaristické proudy $\mathrm{v}$ západoněmecké společnosti působily i nadále, většinová společnost přijala pozitivní obraz vojáka wehrmachtu a do velké míry přikrášlený a neúplný pohled na druhou světovou válku, jak je prezentovali veteráni na svých veřejných osvětových přednáškách, vzpomínkových slavnostech a především ve svých publikacích. Populární paměti bývalých generálů ale i obyčejných vojáků se dále šírily formou triviálních válečných románů a filmů. ${ }^{39}$ Nevyčerpatelným zdrojem válečných zážitků a svědectví o historických událostech očima bývalých generálů a vojáků byla periodika veteránských spolků a svazů. Ta sloužila především vnitřní konsolidaci spolkové identity jednotlivých členů.

Společným jmenovatelem všech těchto textů, kterými veteráni zaplňovali mezeru, již západoněmecká historiografie do té doby nestihla vyplnit, a které

35 „Ehrenmal für die Gebirgstruppe“, Frankfurter Allgemeine Zeitung, 25. května 1957.

36 Až do současnosti si slavnost uchovala stejný dvoudenní rytmus: v sobotu večer neformální setkání $\mathrm{v}$ mittenwaldské pivnici, v neděli kladení věnců k uctění památky padlých obou světových válek před památníkem. Zdravici obvykle pronesl předseda spolku a jeden z významných hostů, poté se konala bohoslužba. O hudební doprovod se starala místní nebo později vojenská kapela mittenwaldské základny horských myslivců.

37 „Das Wort, der Weg, die Begegnung“, Die Gebirgstruppe 6, č. 2-4 (1957): 6-22, zde 18.

38 Wittmann, „4 Jahre Kameradenkreis“, 225.

39 Více viz Wette, Wehrmacht. Obrazy neprítele, 205-6. 
vytvářely rámec pro celospolečenské přijetí legendy o čistém wehrmachtu, byl poukaz na nepolitičnost vojáků. Němečtí vojáci podle této interpretace sice př́sahali Hitlerovi, nicméně nebojovali za systém, ale z lásky k vlasti a domovu, který bránili do posledního dne války před krutým bolševickým systémem. Stylizovali se tak do dvojí role obětí. Nejenže museli projít různými válečnými útrapami, ale navíc byli zneužiti nacistickým režimem. Popis vojenskostrategických aspektů jednotlivých operací a každodenních zážitků $\mathrm{z}$ fronty, svědectví o velkém přátelství a statečnosti, ale i vzpomínky na utrpení a jeho překonávání byly zcela vyňaty z historického kontextu nacistické vyhlazovací války. Umožnily tak nejen mezi veterány, ale i většinovou společností navodit dojem, že vojáci wehrmachtu vedli „normální válku a s nacistickými zvěrstvy neměli nic společného. ${ }^{40}$

Vlastní agresi nad rámec válečných operací tematizovali veteráni ve svých publikacích či veřejných vystoupeních jen zř́dka, většinou v reakci na konkrétní obvinění. Běžnou obrannou strategií byl poukaz na to, že stejně jako v každé válce a na všech stranách mohlo výjimečně dojít k pochybením jednotlivců. Vždy se ovšem jednalo o nevyhnutelné události, které se staly, když se vojáci bránili a reagovali na ještě větší projevy brutality a útoky místních partyzánů nebo když se ocitli v situaci, kdy neuposlechnutí rozkazu znamenalo válečný soud a trest smrti (Befehlsnotstand) ${ }^{41}$ Konkrétní nařčení $\mathrm{z}$ účasti na válečných zločinech veteráni zpravidla odmítali $s$ tím, že se vůbec nestaly, nebo že za ně nebyli odpovědni. Masové zabíjení civilního obyvatelstva v okupovaných zemích v rámci odvetných opatření, za které byli i někteří generálové wehrmachtu odsouzeni v rámci norimberských procesů, bylo vykládáno jako legitimní způsob boje proti partyzánům, nikoliv jako porušení válečného či mezinárodního práva. Rozsudky spojeneckých soudů byly podle tohoto výkladu aktem pomsty a justice vítězů (Siegerjustiz) a odsouzení generálové se po svém propuštění brzy těšili respektu jak u veteránů, tak u široké veřejnosti. ${ }^{42}$ Tak tomu bylo i v př́padě bývalého velitele 1 . horské divize generála Huberta Lanze, který se krátce po svém předčasném omilostnění v roce 1952 stal čestným předsedou Kameradenkreisu. ${ }^{43}$

40 Viz jednotlivé př́spěvky v Die Gebirgstruppe. Obecně k tématu viz Echternkamp, „Mit dem Krieg“, 78-93.

${ }^{41}$ Kühne, „Zwischen Vernichtungskrieg und Freizeitgesellschaft“, 101-2.

42 Např. Werner Daumiller, „Zu treuem Gedenken an General der Gebirgstruppe a.D. Hubert Lanz“, Die Gebirgstruppe 31, č. 3 (1982): 38-44.

${ }^{43}$ Lanz byl v roce $1947 \mathrm{v}$ následném norimberském procesu s dalšími generály wehrmachtu odsouzen americkým tribunálem za válečné zločiny proti řeckým civilistům a italským vojákům na Balkáně, mimo jiné i na Kefalonii, ke dvanácti letům vězení. Viz Trials of War Criminals before the Nuernberg Military Tribunals under Control Council law No. 10, October 1946-April 1949, sv. XI (Washington, 1950), 1311-13, 1319. 
Založení Bundeswehru přineslo spolku bývalých horských myslivců důležitý impuls k rozšíření aktivit a potvrzení smyslu jeho dosavadní existence. Vybudování dvou brigád horských myslivců pod velením bývalých důstojníků wehrmachtu, ve kterých sloužila asi tisícovka veteránů, umožnilo předávání vojenského řemesla, zkušeností a tradičních hodnot mezi „starými“ a „mladými kamarády“.44 Oficiálně měla sice armáda Spolkové republiky být postavena na nových základech, ale díky vlivu bývalých důstojníků wehrmachtu v armádě i na spolkovém ministerstvu vnitra zůstávaly plánované reformy dlouho jen na papíre. ${ }^{45} \mathrm{~V}$ praxi docházelo $\mathrm{k}$ přejímání tradic, rituálů a konvencí wehrmachtu, např́iklad vojenských ceremonií, řádů a vyznamenání, odznaků a názvư jednotek. Jedna z horských brigád tak byla pojmenována po své předchůdkyni $\mathrm{z}$ wehrmachtu jako 1 . horská divize, po níž převzala i označení v podobě květu protěže alpské (Edelweiß). ${ }^{46} \mathrm{~V}$ polovině šedesátých let přijala řada kasáren názvy po generálech reichswehru a wehrmachtu, mimo jiné po bývalých velitelích horských jednotek, generálech Dietlovi, Küblerovi a Konradovi. Pro někdejší spolubojovníky organizované v Kameradenkreisu představovali Eduard Dietl a Ludwig Kübler úctyhodné a zasloužilé vojáky, kterým vděčili za vybudování elitních německých horských jednotek wehrmachtu. ${ }^{47} \mathrm{Sku}$ tečnost, že byli skalními stoupenci nacistické ideologie a za druhé světové války dávali či předávali rozkazy v rozporu s mezinárodním či válečným právem, se veřejnost naopak dlouho neměla od koho dozvědět. ${ }^{48}$

Se založením Ústředí zemských justičních správ pro objasnění nacistických zločinů v Ludwigsburgu v roce 1958 vznikl určitý prostor pro vyšetřování válečných zločinů spáchaných jednotkami SS a wehrmachtu na obsazených územích. ${ }^{49}$ Vyšetřování vedená proti podezřelým příslušníkům wehrmachtu v letech 1960 až 1990 však skončila ve všech případech zastavením řízení. Velký

${ }^{44}$ Hans Buchner, „Die neue deutsche Gebirgstruppe“, Die Gebirgstruppe 6, č. 2-4 (1957): 277-80, zde 280.

45 Wette, Wehrmacht. Obrazy neprítele, 228n. K reformním koncepcím viz Detlef Bald, „Graf Baudissin und die Reform des deutschen Militärs“, in Innere Führung: Zum Gedenken an Wolf Graf von Baudissin, ed. Hilmar Linnenkamp und Dieter S. Lutz (Baden-Baden: Nomos, 1995), 19-53.

${ }^{46}$ Meyer, Blutiges Edelweiß, 670.

47 Ludwig Kübler, Oster-Mitteilungen der ehemaligen deutschen Gebirgstruppen, 1953, 11-22; Karl Wilhelm Thilo, „Gedanken zur Tradition der Gebirgstruppe“, Die Gebirgstruppe 34, č. 2 (1985): 3-7, zde 4.

48 Jakob Knab, „Zeitlose soldatische Tugenden“, Die Zeit, 10. listopadu 2005, http://www.zeit .de/2005/46/A-Bundeswehr.

49 Alfred Streim, „Saubere Wehrmacht? Die Verfolgung von Kriegs- und NS-Verbrechen in der Bundesrepublik und der DDR“, in Vernichtungskrieg. Verbrechen der Wehrmacht 1941-1944, ed. Hannes Heer a Klaus Naumannn (Hamburg: Hamburger Edition, 1995), 569-600. K historii a činnosti ludwigsburského ústředí srov. Anette Weinke, Eine Gesellschaft ermittelt gegen sich selbst: Die Geschichte der Zentralen Stelle Ludwigsburg 1958-2008 (Darmstadt: WGB, 2008). 
podíl na tom měla nedostatečná ochota státních zástupců dovést vyšetřování konkrétních podezřelých $\mathrm{k}$ obžalobě a fakt, že mezi vyslýchanými svědky a podezřelými docházelo $\mathrm{k}$ domlouvání a vzájemnému krytí. ${ }^{50}$ Jednotlivé př́ípady válečných zločinů vzbudily po zastavení vyšetřování pozornost médií jen výjimečně a ještě menší ohlas pak nalezly u západoněmecké veřejnosti. ${ }^{51}$ Detaily $\mathrm{z}$ př́ípadu Kommeno se tak až do devadesátých let $\mathrm{z}$ médií nedozvěděla vůbec; o masakru italských zajatců na Kefalonii a zastavení vyšetřování německé prokuratury v roce 1968 informovalo do konce osmdesátých let jen několik publicistů, $\mathrm{s}$ téměř nulovým ohlasem..$^{52}$ Dotčení veteráni, pokud k těmto zprávám a obviněním zcela nemlčeli, je odmítali jako „nafouknuté lži a účelovou komunistickou propagandu. ${ }^{53}$ Naráželi tím na kampaně řízené z NDR, které skandalizovaly bývalé funkcionáře NSDAP, prrípadně členy dalších nacistických organizací ve státní správě, v řadách soudců, vysokých úředníků, jakož i „fašistické“ důstojníky, kteří dál působili v Bundeswehru. ${ }^{54}$

Kameradenkreis tyto ne přiliš časté mediální útoky na jednotlivé velitele, či celý wehrmacht úspěšně odrážel, protože veteránské spolky obecně měly silnou podporu politických a vojenských elit i u většiny obyvatel Spolkové republiky. Společenská atmosféra se nicméně postupně začala měnit především $\mathrm{v}$ důsledku generační proměny obyvatelstva, která byla citlivější vůči nacistické minulosti generace otců a dědů a přetrvávajícímu autoritářskému charakteru státních i rodinných struktur. Rozvoj občanské společnosti sebou přinesl i aktivní opozici proti ozbrojeným složkám státu, a tím i celé veteránské kultuře. ${ }^{55}$ Od konce sedmdesátých let se mobilizovalo mírové hnutí proti tzv. dvojímu rozhodnutí NATO, ${ }^{56}$ a tím mimo

50 Tuto praxi potvrzuje napr. Schminck-Gustavus, který zkoumal procesní svazky dortmundského státního zastupitelství ve vyšetřování případu Kefalonia. Viz Schminck-Gustavus, Kephalloniá, 153-65.

51 Viz ohlasy na prípad „Kalavryta“ a „Filetto“ v roce 1969 v práci Mikulová, „Případ Kefalonia“, $111-12$.

52 Ibid.

${ }^{53}$ Např. v př́padě „Kefalonie“: „Direktor Rademaker: ,Bin kein Kriegsverbrecher. Beschuldigungen zurückgewiesen“, Die Rheinpfalz, 10. prosince 1969. Více viz Mikulová, „Př́pad Kefalonia“.

${ }^{54}$ Braunbuch, Kriegs- und Naziverbrecher in der Bundesrepublik (Berlin: Staatsverl. der DDR, 1965). Srov. také Nationale Front des Demokratischen Deutschland, ed., Graubuch: Expansionspolitik und Neonazismus in Westdeutschland: Hintergründe, Ziele, Methode: eine Dokumentation (Berlin: Staatsverl. der DDR, 1967).

55 Kühne, „Zwischen Vernichtungskrieg und Freizeitgesellschaft“, 110-11.

56 Toto rozhodnutí počítalo $s$ tím, že v př́padě neúspěšného jednání USA se SSSR bude SRN „dovyzbrojena" atomovými zbraněmi. K mírovému hnutí viz Andreas Buro, „Friedensbewegung“, in Die sozialen Bewegungen in Deutschland seit 1945: Ein Handbuch, ed. Roland Roth a Dieter Rucht (Frankfurt, New York: Campus, 2008), 267-91, zde 283-84. 
jiné vznikla půda pro kontroverzní debaty ohledně branné povinnosti, smyslu Bundeswehru a jeho vztahu k tradicím wehrmachtu.

Na tyto občanské iniciativy a na práce vojenských historiků, kteř́ od konce šedesátých let zkoumali strategii a důsledky útočné a vyhlazovací války Německé rríše, zareagoval v roce 1982 spolkový ministr vnitra druhým výnosem o tradicích Bundeswehru (Traditionserlass). ${ }^{57}$ Dodnes platný dokument vzbudil mezi "tradicionalisty“" $\mathrm{v}$ armádě a uvnitř veteránských spolků velkou nevoli. Na rozdíl od prvního výnosu z roku 1965 jednoznačně odmítl vhodnost odvozování tradic Bundeswehru od svého předchůdce, třebaže slovo wehrmacht se v textu nevyskytuje. Doslovně se v něm hovoří o tom, že režim bezpráví jako Třetí ŕíše nemůže zakládat tradici. Připouští také, že část ozbrojených složek se v době nacismu s tímto režimem „vlastní vinou zapletla“ a zčásti jím byla zneužita „bez vlastního zavinění “ ${ }^{8}$ Prostor pro určitou spolupráci mezi veteránskými spolky a jednotkami Bundeswehru však zůstal i nadále zachován.

Na rozdíl od jiných veteránských spolků, které v osmdesátých letech ztrácely na masovosti, Kameradenkreis bezprostřední hrozbu zániku odvrátil změnou stanov, které do té doby umožňovaly členství jen veteránům wehrmachtu, jejich př́íbuzným, a pozůstalým po padlých. Od roku 1983 se členy mohli stát i aktivní př́slušníci horských jednotek a rezervisté Bundeswehru. ${ }^{59}$ Navíc se spolku podařilo dočasně posílit svou společenskou prestiž tím, že v roce 1985 inicioval založení mezinárodní federace horských vojáků (International Federation of Mountain Soldiers, IFMS). Společně s veteránskými organizacemi z Francie, Itálie, USA a Rakouska si vytkly za cíl smírení a porozumění mezi národy ${ }^{60}$ Kameradenkreis se ovšem stále více musel soustředit na obranu svých dosavadních postojů a aktivit vzhledem $k$ čím dál častějším a masovějším protestům občanských iniciativ a kritice v médiích proti konvencím a tradicím wehrmachtu praktikovaným v Bundeswehru. Asi nejvíce se ho dotkly dlouhodobé protesty proti názvům kasáren a ulic po generálech Dietlovi a Küblerovi

57 Wolfram Wette, „Die Bundeswehr im Banne des Vorbildes Wehrmacht“, in Mythos Wehrmacht. Nachkriegsdebatten und Traditionspflege, ed. Detlef Bald, Johannes Klotz a Wolfram Wette (Berlin: Aufbau-Taschenbücher, 2001), 66-115, zde 84-86.

58 Viz bod 6, „Richtlinien zum Traditionsverständnis und zur Traditionspflege in der Bundeswehr“, oficiální stránky spolkového ministerstva obrany: http://www.bundeswehr.de/portal/a/bwde/!ut/p/ c4/RYsxDoAgDADf4gfo7uYv1K1AhQaCpq3yfXEyt1wuOdhh0PDhhMZnwworbIFn353vkZyaEF sRpMPIJblbrJiouUQaMoc8qglG_u7flKSiKlxlmV4qpIts/.

59 Samostatná brožurka se stanovami a řády vyšla jako př́loha časopisu Die Gebirgstruppe. „Satzung und Ordnungen, Satzung, Fassung vom 7. November 1982“, 3-7. Jen díky tomu mohl Kameradenkreis vykázat v roce 2000 přibližně stejný počet členů (7362) jako v roce 1987. Viz „Mitteilungen des Vorstandes“, Die Gebirgstruppe 49, č. 3 (2000): 62-64.

${ }^{60}$ Viz oficiální stránky IFMS: http://www.kamkreis-gebirgstruppe.de/ifms.htm. 
od poloviny osmdesátých let. ${ }^{61}$ Ve stejné době začaly být medializovány také některé válečné zločiny spáchané jednotkami horských myslivců jako masakr na Kefalonii či odvetná opatření proti civilistům v rámci boje proti partyzánům v Řecku. ${ }^{62}$

Bývalí horští myslivci, jednotlivě nebo organizovaně jako celek, se bránili proti takovému „hanobení “ cti svých „kamarádü“ osvědčeným způsobem: podepisovali petice, posílali otevřené i soukromé dopisy na adresu vysokých státních představitelů a čtenářské dopisy k publikaci v médiích. Svůj postoj opíral Kameradenkreis jak o některé revizionistické studie, tak především o vzpomínky a líčení válečných veteránů publikovaná v časopise Die Gebirgstruppe. Ti zločinný charakter jednotlivých rozkazů a operací bud' prímo popírali, nebo relativizovali, tím že snižovali rozsah masakrů nebo poukazovali na různé „polehčující okolnosti“.63

Konec studené války a znovusjednocení Německa přinesly Bundeswehru nové vnitro- i zahraničněpolitické výzvy, mezi jinými potřebu nově strukturovat a zreformovat německou armádu po začlenění východoněmeckého vojska, či rozšíření kompetencí armády mimo území Spolkové republiky. Už od roku 1991 se příslušníci německého vojska včetně horských myslivců začali pravidelně účastnit zahraničních mírových misí Organizace spojených národů a počínajíce kosovskou krizí v roce 1999 i vojenských intervencí NATO v bývalé Jugoslávii, Afghánistánu a dalších zemích. Tento vývoj vzbuzoval nejen u části levicově orientované populace obavy z nové militarizace společnosti. Ty se projevovaly formou demonstrací proti vojenským ceremoniím na veřejnosti nebo poškozování pomníků padlým vojákům wehrmachtu, ${ }^{64}$ soudními spory ohledně beztrestného používání a modifikace Tucholského citátu „vojáci jsou vrazi“" 65 až po protestní akce za zrušení Bundeswehru.

Nejdalekosáhlejší dopad na už tak oslabenou veteránskou kulturu měla putovní výstava Vyhlazovací válka. Zločiny wehrmachtu 1941 až 1944, která prošla v letech 1995 až 1999 více než třemi desítkami německých a rakouských měst a všude vyvolávala bouřlivé reakce pamětníků, politiků, laiků i historiků. Třebaže byla za účelem prošetření některých odborných výtek ukončena, po zjištění, že

${ }^{61}$ Jakob Knab, „Zeitlose soldatische Tugenden“, Die Zeit, 10. listopadu 2005, http://www.zeit .de/2005/46/A-Bundeswehr. Srov. „Kampagne gegen Generaloberst Dietl“, Die Gebirgstruppe 36, č. 6 (1987): 46-47; „Mitteilungen des Vorstandes und der Schriftleitung: Kampagne gegen Generaloberst Dietl“, Die Gebirgstruppe 37, č. 2 (1988): 40.

62 Viz reakce Kameradenkreisu několika články pamětníků o operaci na Kefaloni, boji proti řeckým partyzánům a operaci Merkur na Krétě v Die Gebirgstruppe 37, č. 1 (1988), 3-21.

63 Ibid.

${ }^{64}$ Např̀. v Tübingenu v roce 1996, viz Kühne, „Zwischen Vernichtungskrieg und Freizeitgesellschaft“, 97-98.

65 Více viz Michael Hepp a Viktor Otto, ed., Soldaten sind Mörder. Dokumentation einer Debatte (Berlin: Ch. Links, 1996). 
se jednalo většinou jen o formální pochybení, byla výstava s pozměněným konceptem v letech 2001 až 2004 obnovena. ${ }^{66}$ Hlavní zásluhou obou výstav bylo to, že dokázaly zprostředkovat dlouho známé historické poznatky široké veřejnosti, včetně toho, že velení wehrmachtu samo plánovalo útočnou a vyhlazovací válku proti Sovětskému svazu a že vydávalo zločinné rozkazy porušující i tehdy platné mezinárodní právo. Dodnes sice přetrvávají rozpory okolo otázky, nakolik se př́slušníci wehrmachtu podíleli na holocaustu a masovém vyvraždování civilistů a především sovětských válečných zajatců na obsazených územích, přesto lze na základě četnosti a rozsahu prokázaných př́padů rozhodně vyloučit, že by se jednalo - slovy př́znivců legendy o čistém wehrmachtu - o „absolutní výjimky“, „selhání jednotlivcü“ či „okrajové jevy“, běžné v kterékoliv jiné armádě.

Kameradenkreis v reakci na výstavu rozhodně odmítal „údajně nové poznatky“, které považoval za překrucování faktů a falšování historie. V duchu známých obranných strategií to označil za paušální urážku na cti celé generace vojáků wehrmachtu a nenávistnou propagandu jedinců a skupin, kteří sledují jiné cíle než pravdu. ${ }^{67} \mathrm{O}$ to naléhavěji pak místopředseda spolku Gerhart Klamert v souvislostí se slavností na Hohe Brendten vyzýval k obraně těch, kteří se už před touto nespravedlností nemohou bránit. Podle jeho slov padlí „kamarádi“ pevně věřili, že musejí bojovat za obranu země a svých rodin a přitom trpěli, hladověli a umírali $\mathrm{v}$ dobré víre, že z jejich oběti povstane lepší svět. Žijící měli proto podle Klamerta povinnost vzpomínat na ty, jimž vděčí za svůj život, s uznáním a vděčností. ${ }^{68}$

Od poloviny devadesátých let nicméně přicházely stále nové impulsy, které zpochybňovaly dosavadní pohled Kameradenkreisu na charakter a průběh druhé světové války a na roli horských myslivců v této válce. V roce 1995 schválilo spolkové ministerstvo obrany změnu názvů kasáren, která do té doby nesla jména generálů Dietla a Küblera. Německá média informovala o částečně úspěšných iniciativách řeckých přeživších a pozůstalých po obětech válečných masakrů vymáhat finanční odškodnění od Spolkové republiky soudní cestou. ${ }^{69}$ Ve stejné době se

${ }^{66}$ Více k diskusím k oběma výstavám viz Tim Seidenschnur, Streit um die Wehrmacht. Die Debatten um die Wehrmachtsausstellungen im Wandel der Generationen (Marburg: Tectum-Verl., 2010).

67 Viz Gerhart Klamert, „Ein Anschlag auf die Wahrheit. Anmerkung zur Ausstellung „Vernichtungskrieg, Verbrechen der Wehrmacht 1941 bis 1945“, Die Gebirgstruppe 46, č. 1 (1997): 3-5; Franz W. Seidler, „Pauschale Verurteilung verunglimpft einzelne“, Die Gebirgstruppe 46, č. 2 (1997): 26-29.

68 Gerhart Klamert, „Totengedenken“, Die Gebirgstruppe 46, č. 4 (1997): 3-4.

69 Jako první podali u řeckého soudu žalobu proti Spolkové republice Německo právní zástupci obětí válečného masakru v obci Distomo v roce 1995. O dva roky později rozhodl soud v jejich prospěch. Rozsudek byl potvrzen i nejvyššími řeckými soudy v letech 2000 a 2002, jeho vykonání ale nakonec zabránil řecký ministr spravedlnosti, když nevydal souhlas s exekucí německého majetku. Viz Kateřina Králová, Nesplacená minulost: řecko-německé vztahy ve stínu nacismu (Praha: Karolinum, 2012), 235-41. 
předmětem nového vyšetřování italské i německé prokuratury staly do té doby vůbec či málo známé válečné zločiny jednotek SS a wehrmachtu v Itálii. ${ }^{70}$ Pod tlakem těchto informací sdělovacích prostředků, ale i historických studií a v reakci na aktivity nových občanských iniciativ, se i uvnitř Kameradenkreisu začaly objevovat názory, které existenci některých válečných zločinů opatrně připouštěly, zároveň však za ně dávaly vinu oběma zúčastněným stranám.

Př́kladem jsou postoje významných členů Kameradenkreisu k masakru řeckých civilistů v Kommenu a italských zajatců na Kefalonii. Ještě v srpnu 2001 tehdejší 2. předseda spolku Klamert, sám válečný veterán, zcela odmítl možnost, že by $\mathrm{v}$ Kommenu došlo $\mathrm{k}$ brutalitám popisovaným v odborné literatuře a médiích. Podle něj šlo o „ľ̌ivé pomluvy“, které zakrývají jiné cíle. ${ }^{71}$ Jiný člen, Klaus Hammel, o půl roku později skutkovou podstatu zločinu nepopřel. Celou událost ale relativizoval s poukazem na vyšetřování př́padu německou justicí, zastavené v sedmdesátých letech. Z něj podle Hammela vyplývala nevěrohodnost řeckých svědků a nízký počet pachatelů, protože většina německých vojáků s masakrem nesouhlasila. ${ }^{72}$

V reakci na medializaci historických událostí a obnoveného vyšetřování případu Kefalonia německým státním zastupitelstvím vyšly v časopise Die Gebirgstruppe v rozmezí jednoho roku hned tři články k tomuto tématu. Jako první zpochybnil Klamert důvěryhodnost mediálního obrazu události. Uznal, že to, co se stalo, byl nehumánní akt proti mezinárodnímu právu, ale okolnosti i počet obětí je ještě třeba vyšetřit, a to především s pomocí německých svědkủ..$^{73}$ Gerd Meyer, tehdejší člen představenstva, byl ve svém odsudku jednoznačnější. Sice vyzdvihl polehčující okolnosti, a tím postavil německé velení a vojáky do nevyhnutelné situace, za kterou nesly vinu jen částečně. Také ale uznal, že se na Kefalonii stal těžký válečný zločin bez ohledu na to, kolik tisíc zajatců přesně bylo zastřeleno. Vyjádřil politování a zároveň přesvědčení, že Kameradenkreis nesmí tyto události vytěsňovat. Jen přiznáním i k temným stránkám minulosti mohou podle Meyera členové Kameradenkreisu i nadále zůstat hrdi na tradici horských myslivců. ${ }^{74}$

${ }^{70} \mathrm{~K}$ pozadí skandálu okolo dlouho utajovaných vyšetřovacích spisů německých válečných zločinů proti italským civilistům viz Kerstin von Lingen, „Od ,mýtu rezistence ke ,skř́ni hanby‘ Nepotrestané válečné zločiny v Itálii (1945-2005)“, Acta Universitatis Carolinae - Studia Territorialia, ed. Jiř́ Pešek, sv. 8 (Praha: Nakladatelství Karolinum, 2005), 155-66.

${ }^{71}$ Gerhart Klamert, „Stichwort Kommeno: Die Wirklichkeit ist nur ein Teil der Wahrheit“, Die Gebirgstruppe 50, č. 4 (2001): 27-28.

72 Klaus Hammel, „Die Feldzüge des Jakob Knab“, Die Gebirgstruppe 51, č. 1 (2002): 8-13, zde 11.

${ }^{73}$ Gerhart Klamert, „Liebe Kameraden, Kephallonia - um was geht es?“, Die Gebirgstruppe 50, č. 3 (2001): 5-7.

74 Gerd R. Meyer, „Kephalonia im September 1943. Versuch einer militärgeschichtlichen Einordnung“, Die Gebirgstruppe 50, č. 5/6 (2001): 29-32. 
Poslední slovo ovšem dostal někdejší účastník operace na Kefalonii Werner Funke. Ohradil se proti tvrzení novinářủ i protestujících, že na Kefalonii bylo zastřeleno 4000 až 5000 italských zajatců. Za pravděpodobné považoval dodatečnou popravu několika vyšších důstojníků, ovšem sám byl svědkem zastřelení pouze 30 zajatců, kteři se „vzbouřili“ ${ }^{75}$ Klamert jeho prríspěvek komentoval s tím, že každý má právo na pravdu, kterou zažil, a že Kameradenkreis stojí za těmi bývalými příslušníky horských myslivců, kteř́ se chovali férově a jsou neprávem obviňováni a očerňováni. ${ }^{76}$

V roce 2001, ve kterém Kameradenkreis slavil 50. výročí od svého založení, byla v rámci reforem tehdejšího spolkového ministra obrany Rudolfa Scharpinga zrušena 1. horská divize. ${ }^{77}$ Rozhodnutí, že jen část těchto elitních vojáků přejde coby horská brigáda 23 pod velení 10. tankové divize, prrijal Kameradenkreis s trpkostí i obavou o budoucnost spolku, který už tak bojoval s trvalým úbytkem členské základny. ${ }^{78}$ Bez ohledu na to vyslovil předseda spolku Griessinger na počátku roku 2001 uspokojení z výsledků dosavadní činnosti Kameradenkreisu a nad jeho pevným postavením ve společnosti i přses její zlomové proměny. Zároveň ujistil všechny členy v odhodlanosti dál usilovat o obranyschopnou demokracii a porozumění mezi národy $\mathrm{k}$ udržení míru a svobody. ${ }^{79}$

\section{Cíle protestní kampaně v Mittenwaldu}

Počátky kampaně sahají k původně malému a jednorázovému protestu skupiny asi padesáti žen a mužů z května roku 2002. S megafony, transparenty a letáky tehdy překvapili asi dvě stovky bývalých a aktivních horských myslivců během neformálního posezení v pivnici, které se koná vždy v předvečer každoročního setkání všech členů Kameradenkreisu v Mittenwaldu. ${ }^{80}$ Protest měl formu happeningu, v jehož

75 Werner Funke, „Kephalonia, Kephalonia - und kein Ende“, Die Gebirgstruppe 51, č. 2 (2002): 17-22.

76 Gerhart Klamert, „In eigener Sache. Der Preis für die Freiheit der Analyse besteht in besonderen Anstrengungen", Die Gebirgstruppe 51, č. 2 (2002): 15-16.

77 Ohlas na poslední nástup 1. horské divize v červnu 2001 viz Hans Lindinger, „Abschlußappell der 1. Gebirgsdivision und Großer Zapfenstreich in Garmisch-Partenkirchen“, Die Gebirgstruppe 50, č. 4 (2001): 3-5.

78 Viz např. Hans Lindinger, „Nachruf auf eine stolze Truppe“, Die Gebirgstruppe 50, č. 4 (2001): 22-23.

79 Karl-R. Griessinger, „Liebe Kameradinnen und Kameraden“, Die Gebirgstruppe 50, č. 1 (2001): 3-4.

${ }^{80}$ Jedno z prvních prohlášení aktivistů pro veřejnost publikované na alternativní informační internetové platformě indimedia.de: „Deutsche PolizistInnen verhindern Schweigeminute“, Indymedia, 20. května 2002, http://de.indymedia.org/2002/05/22370.shtml. Srov. pozdější popis události jednoho z účastníků: Gerhard Polt, „Mein Opa ist Kriegsverbrecher und wohnt in Mittenwald“, nadir, 3. dubna 2003, http://nadir.org/nadir/kampagnen/mittenwald/texte/Mein-Opa-ist-Kriegsverbrecher-undwohnt-in-Mittenwald.html. Srov. Ralph Klein, Regina Mentner a Stephan Stracke, „Mörder unterm 
rámci aktivisté vyzvali k uctění minutou ticha památku civilních obětí masakrů, kterých se př́slušníci horských divizí wehrmachtu dopustili za druhé světové války. Výsledkem byla hlasitá slovní přestřelka mezi oběma skupinami, při které podle svědectví aktivistů padaly i rány pěstí či kopance ze strany př́tomných vojáků a veteránů. ${ }^{81}$ Všem „anarchistům a narušitelům“, jak je později nazval zástupce veteránů, se nicméně podařilo $z$ pivnice bez větší úhony uniknout ještě před prríchodem policie. ${ }^{82}$

Následující den se v horách nad Mittenwaldem sešlo téměř dva a půl tisíce bývalých př́slušníků horských divizí wehrmachtu a jejich následovníků v Bundeswehru v nerušené, sváteční atmosfére. ${ }^{83}$ Spolu se svými rodinami a přáteli, delegacemi zahraničních veteránů, vysokými důstojníky Bundeswehru, zástupci místních politiků a folklórních spolků tam stejně jako každou svatodušní neděli od roku 1957 přišli společně uctít památku padlých z první a druhé světové války. Skupina demonstrantů, kterou místní policie vypátrala v nedaleké ubytovně, byla $\mathrm{v}$ tu dobu na několik hodin zadržena. Později téhož dne se část $\mathrm{z}$ nich ještě pokusila v Mittenwaldu uspořádat spontánní manifestaci proti setkání veteránů, ale policie jim v tom zabránila. ${ }^{84}$

V dalším roce se již konala dlouho připravovaná a mediálně sledovaná dvoudenní manifestace proti setkání horských myslivců v Mittenwaldu, kterou zorganizovali někteří z původních účastníků protestu s dalšími skupinami a jednotlivci. ${ }^{85}$

Edelweiß: ,Eine Selbsthilfegruppe für Kriegsverbrecher"', in Mörder unterm Edelweiß: Dokumentation des Hearings zu den Kriegsverbrechen der Gebirgsjäger, ed. Ralph Klein, Regina Mentner a Stephan Stracke (Köln: PapyRossa-Verl., 2004), 7-23, 11. Udávaný počet protestujících se v různých zdrojích liší od 20 do 60 mužů a žen.

${ }^{81}$ Protestující skandovali názvy míst jednotlivých válečných zločinů a hesla tematizující horské myslivce jako vrahy. Agresivním nadávkám a snaze vojáků vytlačit demonstranty z pivnice ven čelili aktivisté podle vlastního líčení nenásilným zpơsobem (křikem z bezprostřední blízkosti, úhybnými manévry apod.). Více viz „Deutsche PolizistInnen verhindern Schweigeminute“, Indymedia, 20. května 2002, http://de.indymedia.org/2002/05/22370.shtml; Gerhard Polt, „Mein Opa ist Kriegsverbrecher und wohnt in Mittenwald“, nadir, 3. dubna 2003, http://nadir.org/nadir/ kampagnen/mittenwald/texte/Mein-Opa-ist-Kriegsverbrecher-und-wohnt-in-Mittenwald.html. Naproti tomu zástupce bývalých horských myslivců vyzdvihoval klid a sebekontrolu, $s$ jakou na „narušitele“ reagovali. Viz „Gedenkfeier am Hohen Brendten 2002“, Die Gebirgstruppe 51, č. 3 (2002): 4-5, zde 4 .

82 „Gedenkfeier am Hohen Brendten 2002“, Die Gebirgstruppe 51, č. 3 (2002): 4-5, zde 4.

83 Ibid., 5.

84 „Deutsche PolizistInnen verhindern Schweigeminute“, Indymedia, 20. května 2002, http:// de.indymedia.org/2002/05/22370.shtml. Srov. „Alpenglühen - Ungebrochene Kontinuität: Über die Traditionspflege der Gebirgsjäger“, nadir, nedatováno, http://nadir.org/nadir/kampagnen /mittenwald/texte/Alpengluehen-Ungebrochene-Kontinuitaet-ber-die-Traditionspflege-der -Gebirgsjaeger.html.

${ }^{85}$ Rozhodnutí o konání nové demonstrace padlo v létě 2002, kdy historici zapojení do pracovní skupiny Napadnutelná péče o tradice prováděli historické rešerše k válečným zločinů wehrmachtu v Řecku. Viz Klein, Mentner a Stracke, „,Dokumentation und Aktion“', 207. 
Hlavní organizátoři se nazvali pracovní skupinou Napadnutelná péče o tradice. Spolu s VVN-BdA, pracovní skupinou Distomo a dalšími skupinami a jednotlivci, kteří se $\mathrm{v}$ pozdějších letech $\mathrm{k}$ protestujícím přidávali, tvořili levicově orientovanou iniciativu, která pokrývala poměrně širokou škálu požadavků a cílů. Ne vždy se na nich všechny protestní skupiny shodovaly. Jako společné lze označit tři hlavní okruhy témat, která byla $\mathrm{v}$ hrubých rysech definována již v roce 2002 a později byla už jen prohlubována, lehce modifikována a doplňována o nová. ${ }^{86} \mathrm{Na}$ prvním místě stála veřejně deklarovaná solidarita a podpora požadavků na finanční odškodnění, které vưči německému státu vznášela asociace řeckých přeživších a pozůstalých po obětech válečných zločinů spáchaných v době německé okupace. Druhým požadavkem, směřovaným k německé justici, bylo bezodkladné stíhání a potrestání dosud žijících horských myslivců wehrmachtu, kteří byli odpovědni za konkrétní válečné zločiny, a to nejen v Řecku. Konečně třetím, ale neméně důležitým cílem, od něhož hlavní organizátor kampaně odvozoval svůj název, bylo napadnout samotnou „péči o tradice“ bývalých a současných horských myslivců. ${ }^{87}$

K třetímu bodu kritiky aktivisty motivovala dosavadní činnost a postoje veteránů druhé světové války, kteří ještě v roce 2002 popírali desítky více či méně známých válečných zločinů spáchaných horskými myslivci, př́padně je relativizovali coby legitimní válečný prostředek. $Z$ pohledu protestujících veteráni veřejně a nerušeně „oslavovali“ padlé „kamarády“, jakož i samy sebe coby čestné a statečné vojáky, kteří se stali obětí nacistického režimu a války. Někdejší pachatelé a jejich „kamarádi“ se tak svým vzpomínáním na velké výkony z fronty a uctíváním padlých „hrdinư “ doslova „vysmívali“ skutečným obětem války, zvláště pak obětem těch masakrů, jež spáchali sami horští myslivci wehrmachtu. Kritika demonstrantů mírila zároveň i na místní obyvatele za to, že veteránská setkání v Mittenwaldu podporovali, a hlavně na důstojníky a vojáky Bundeswehru za to, že tradice svých předchůdců ve wehrmachtu, včetně tradovaného popírání či zamlčování válečných zločinů, nekriticky přejímali a dále udržovali. ${ }^{88}$

S třetím jmenovaným cílem kampaně také souvisel důvod, proč se hlavní protesty odehrávaly právě v Mittenwaldu - v malém a od velkých center poměrně vzdáleném

86 „Deutsche PolizistInnen verhindern Schweigeminute“, Indymedia, 20. května 2002, http:// de.indymedia.org/2002/05/22370.shtml. Srov. Klein, Mentner a Stracke, „Mörder unterm Edelweiß“, 13.

87 Podle definice historiků spolupracujících s pracovní skupinou Napadnutelná péče o tradice rozuměli pod tímto souslovím soubor všech sociálních praktik, které sloužily $\mathrm{k}$ vytvoření vojenského společenství, jeho udržování směrem dovnitř a formování identity a vlastního obrazu navenek, s cílem stát se relevantním aktérem ve veřejném diskursu. Cit. podle Gronau, Aufblinde Flecken zeigen, 79.

88 „Deutsche PolizistInnen verhindern Schweigeminute“, Indymedia, 20. května 2002, http:// de.indymedia.org/2002/05/22370.shtml. 
městě uprostř̌ed bavorských Alp. Monumentální pomník na blízké hoře Hohe Brendten byl místem každoročního setkávání všech bývalých i aktivních horských myslivců za účasti vysokých zástupců Bundeswehru a tím zcela zřejmým symbolem uctívání a uchovávání tradic horských myslivců, tak jak je Kameradenkreis definoval při svém založení. Jak napsal v roce 2001 tehdejší místopředseda Kameradenkreisu, bývalí i aktivní vojáci se zde sešli, aby společně uctili památku padlých a připomněli si jejich „statečnost, věrnost, lásku k vlasti, skromnost a nezištnost“" 89 Zatímco přítomnost stávajícího velitele 1. horské divize Bundeswehru i jeho dvou předchůdců měla dokládat „př́íladnou kontinuitu“; účast zástupců zemské a komunální politiky měla dokumentovat hluboké spojení mezi aktivními horskými jednotkami, Kameradenkreisem a místními obyvateli. ${ }^{90}$ Ještě v devadesátých letech minulého století se setkání na Hohe Brendten účastnilo pět tisíc až deset tisíc osob. Patřilo tak v té době k největším setkáním bývalých a aktivních vojáků, včetně veteránů druhé světové války. ${ }^{91}$

Organizátoři protestní kampaně si tak pro svou kritiku péče o tradice horských myslivců nemohli vybrat vhodnější místo - zvlášt proto, že postupem času nezůstali jen u vznášení požadavků směrem k německé justici, politikům, městské radě Mittenwaldu a celé veřejnosti, ale sami chtěli stávající situaci změnit. Jednak se všemožnými způsoby snažili - přes zákazy demonstrací a bezpečnostní opatření policie - zabránit konání vzpomínkové slavnosti na Hohe Brendten nebo alespoň narušit její klidný průběh. Jednak zakládali novou „tradici oběti“ $v$ opozici vůči „tradici vrahů a pachatelü“: vedle toho, že v městečku Mittenwald stavěli dočasné symbolické pomníky obětem masakrů, které jednotky horských myslivců spáchaly za druhé světové války, pravidelně také zvali historiky a přeživší či pozůstalé po obětech, aby o těchto událostech referovali či podali svá svědectví.

Když kampaň její organizátoři po sedmi letech oficiálně ukončili, mohli se prokázat dílčími úspěchy. V srpnu 2009 německá justice vůbec poprvé od konce války odsoudila bývalého př́slušníka horských myslivců wehrmachtu za podíl na válečném zločinu proti civilistům..$^{92}$ Protestující, kteří na případ Josefa

${ }^{89}$ Harald Rettelbach, „Ehrenmale - Gedenksteine - Gedenktafel der deutschen Gebirgstruppe“, Die Gebirgstruppe 50, Sonderheft (ř́ijen 2001): 29.

90 „Brendtenfeier 2001“, Die Gebirgstruppe 50, č. 4 (2001): 23-27.

91 Např. Helmut Prior, „Hoher Brendten 1992 - ein Höhepunkt. 10000 kamen zum 35jährigen Jubiläum des Ehrenmales“, Die Gebirgstruppe 41, č. 4 (1992): 4-8.

92 Mnichovský soud rozhodl, že tehdejší velitel horského ženijního praporu byl spoluodpovědný za smrt deseti mužských obyvatel vesnice Falzano di Cortona. Scheungraberovi byl vyměřen trest odnětí svobody na doživotí, ten ale ze zdravotních důvodů nikdy nenastoupil, což v roce 2011 potvrdil i soud. Viz Christian Rost, „NS-Kriegsverbrecher zu krank fürs Gefängnis“, Süddeutsche Zeitung, 11. srpna 2011, http://www.sueddeutsche.de/muenchen /josef-scheungraber-haftunfaehig-ns-kriegsverbrecher-zu-krank-fuers-gefaengnis-1.1130026. 
Scheungrabera dlouhodobě upozorňovali a požadovali jeho potrestání i v rámci menších manifestací v místě jeho bydliště, na tom sice neměli přímou zásluhu, ale díky soudnímu výroku, který dodatečně potvrzoval jejich argumentaci a oprávněnost jednoho z požadavků, cítili zadostiučinění. $O$ rok později uzavřely pak pracovní skupina Napadnutelná péče o tradice a zastupitelstvo Mittenwaldu dohodu o tom, že město přijme dar v podobě pomníku věnovaného obětem zavražděným horskými myslivci wehrmachtu a umístí jej na důstojném místě.

\section{Kameradenkreis versus Napadnutelná péče o tradice}

Z dnešního pohledu vyčnívají demonstrace v Mittenwaldu mezi dřívějšími protesty různých občanských iniciativ coby kampaň nebývale intenzivní, různorodá a úspěšná při mobilizaci médií na celostátní úrovni. Její počátky v roce 2002 však ničemu takovému nenasvědčovaly. Co do argumentů a požadavků se př́liš nevymykaly $\mathrm{z}$ řady veřejných konfrontací namírených proti péči o tradice horských myslivců v Bundeswehru v prèedchozích letech. ${ }^{93}$ Protest proti pevné soudržnosti vojáků Bundeswehru s bývalými příslušníky „fašistického wehrmachtu“ a demonstrované při uctívání „nacistických generálü“ a „vrahư“ na Hohe Brendten dotčené členy Kameradenkreisu překvapil spíše troufalostí aktivistů přijít na místo tradičně vyhrazené jim samým než obsahem jejich hesel a požadavků. ${ }^{44} \mathrm{Z}$ bezprostředních reakcí předsednictva přitom vyplývá, že ani tak této události př́lišný význam nepřikládalo. Bylo v nich patrno uspokojení nad tím, že asi dvacetiminutový výstup „mladých radikálü“ nenarušil poklidnou atmosféru setkání, a to i díky policii, která následující den skupinu protestujících zajistila, a předešla tak dalším přestupkům..$^{95}$

Také následné mediální pozdvižení, které málem skončilo před soudem, nechávalo představitele Kameradenkreisu klidnými. Na základě záznamů, které novináři natočili během letnicového setkání, bylo na několik veteránů podáno

${ }^{93}$ Mezi nejvytrvalejší aktivisty patřil Jakob Knab, původně člen mírové skupiny Pax Christi, která už od poloviny osmdesátých let požadovala přejmenování kasáren a ulic pojmenovaných po generálech Dietlovi a Küblerovi a dalších nacistických generálech. Knab později založil iniciativu „proti falešné slávě“ (Initiative gegen falsche Glorie) a spolu s Pax Christi a stranou Zelených se mimo jiné veřejně zasazoval proti plánovanému muzeu horských myslivců v Sonthofen. Viz „Kritische Töne zum Gebirgsjägermuseum“, all-in.de, 3. srpna 2001, http://www.all-in.de/nachrichten/lokales/Kritische -Toene-zum-Gebirgsjaegermuseum;art26090,159465; srov. pohled Kameradenkreisu: Klaus Hammel, „Die Feldzüge des Jakob Knab“, Die Gebirgstruppe 51, č. 1 (2002): 8-13.

94 Citace viz prohlášení aktivistů „Deutsche PolizistInnen verhindern Schweigeminute“, Indymedia, 20. května 2002, http://de.indymedia.org/2002/05/22370.shtml.

95 „Gedenkfeier am Hohen Brendten 2002“, Die Gebirgstruppe 51, č. 3 (2002): 4-5, zde 4. 
trestní oznámení za používání symbolů zakázaných organizací. 96 Člen předsednictva spolku Harald Rettelbach vyjádřil politování nad touto událostí s tím, že šlo o „kamarády“ $z$ Rakouska, u nichž je nošení válečných vyznamenání v původní podobě, tedy i se symbolem hákového kř́že, povoleno. ${ }^{97}$ Odmítl obvinění, že by dotyční byli nacisty, nicméně slíbil, že pro př́ště budou vyzváni, aby vyznamenání nevystavovali na odiv. ${ }^{98}$ Někdejši ředitel tiskového centra NATO také v rozhovoru s novinářem připustil, že na Kefalonii nepochybně došlo k zločinu, ale pokud někomu nebyla prokázána individuální vina, pokračoval Rettelbach, nepřipadá jeho vyloučení ze spolku v úvahu. ${ }^{99}$

Nicméně už po několika měsících bylo jasné, že ani další ročník setkání na Hohe Brendten se neobejde bez velké pozornosti médií a blízké přítomnosti jeho kritiků. Už od listopadu 2002 začala budoucí pracovní skupina Napadnutelná péče o tradice společně s VVN-BdA připravovat tzv. Hearing, veřejné slyšení historiků, svědků a přeživších, kteří by mluvili mimo jiné o krvavých událostech v Kommenu, Distomu a na Kefalonii. Organizátoři kampaně s předstihem iniciovali v celoněmeckých médiích články a reportáže o jednotlivých válečných episodách, které končili masakrem civilistů nebo zajatých vojáků. Zároveň informovali o požadavcích řeckých obětí na odškodnění. Prostřednictvím svých stránek a alternativních informačních platforem na internetu dlouhodobě mobilizovali $\mathrm{k}$ účasti na manifestaci a protestech př́mo v Mittenwaldu. ${ }^{100} \mathrm{Na}$ dvoudenní akci během letnicového víkendu se pak vedle 200 až 450 účastníků protestu sjeli novináři tištěných médií, rozhlasu a televize z celého Německa i ze zahraničí. ${ }^{101}$

Z obavy o poškození dobrého jména se představitelé Kameradenkreisu pokusili o mediální protiútok. Snažili se veřejnosti blíže představit svůj pohled na péči o vojenské tradice, její smysl, jakož i postoj Kameradenkreisu ke zločinům horských myslivců za druhé světové války a tomu, jakým způsobem se s nimi

96 Klein, Mentner a Stracke, „Mörder unterm Edelweiß“, 11-12.

97 Christof Schnürer, „Kriegsveteranen tragen Orden mit Hakenkreuzen - Beschwerdebrief an Hardthöhe“, Garmisch-Partenkirchner-Tagblatt, 5. června 2002.

98 Ibid.

99 Joachim Tornau, „NS-Orden stören den soldatischen Schulterschluss in Mittenwald nicht“, Frankfurter Rundschau, 21. května 2002.

100 Oficiální výzva pracovní skupiny Napadnutelná péče o tradice viz „Alpenglühen - Ungebrochene Kontinuität: Über die Traditionspflege der Gebirgsjäger“, nadir, nedatováno, http://nadir.org/nadir /kampagnen/mittenwald/texte/Alpengluehen-Ungebrochene-Kontinuitaet-ber-die-Traditionspflege -der-Gebirgsjaeger.html.

101 Počet účastníků viz Gronau, Auf blinde Flecken zeigen, 98. Srov. zprávu z akce „Erster Bericht von den Aktionen Pfingsten 2003“, nadir, nedatováno, http://nadir.org/nadir/kampagnen/mittenwald /texte/Erster-Bericht-von-den-Aktionen-Pfingsten-2003.html. 
vyrovnává. Větší prostor však dostali pouze v lokálních novinách. ${ }^{102} \mathrm{O}$ to víc se těmto tématům věnovalo dubnové vydání Die Gebirgstruppe, ve kterém čerstvý předseda Kameradenkreisu Coqui shrnul stanoviska předsednictva k proběhnuvšímu setkání z Hohe Brendten. Do jasného protikladu přitom postavil veteránský spolek a demonstranty. Na jedné straně stál Kameradenkreis coby organizace, která ctí ústavu a svobodný demokratický právní stát. Tím se jeho předseda nepřímo ohradil proti nařčení, že spolek sdružuje „staré nacisty“, případně podporuje extrémně pravicové síly. Na druhé straně mělo stát sdružení VVN-BdA, které bylo veteránům známo $\mathrm{z}$ dřivějších konfrontací. Coqui přitom poukázal na aktuální zprávu spolkového úřadu pro ochranu ústavy, ve které byla tato organizace přiřazena $\mathrm{k}$ levicovému extremismu, a tím de facto označil všechny požadavky protestujících za nelegitimní. ${ }^{103}$

Ve stejném smyslu se vyjadřovali i další zástupci spolku, kteří výslovně odmítli jakýkoliv dialog s „netolerantními“ nepráteli demokracie, kteří se neštítí násilí. ${ }^{104}$ Podle mluvčího Behringera si od nich Kameradenkreis nemusí nechat ř́kat, jak mají pečovat o tradice a koho si mají připomínat. Oni sami vědí, že ten jejich způsob je správný, protože hodnoty, které svými tradicemi uchovávají, se kryjí s ústavním pořádkem Spolkové republiky. Kameradenkreis udržuje v povědomí mladé generace to nejlepší z minulosti horských myslivců. Tam ale, jak pokračoval Behringer, zločiny nepatří. ${ }^{105} \mathrm{~V}$ podobném duchu se vyjádřil i předseda Coqui ve zmíněném stanovisku: Kameradenkreis si je vědom válečných zločinů, které se staly. Už léta je dokumentuje a podporuje jejich historické zpracování. Tradici ale nezakládají. ${ }^{106}$ Vůbec poprvé pak jménem celého spolku výslovně a jednoznačně odsoudil „bezprávi“ na Kefalonii a v Kommenu. ${ }^{107}$ Hned k tomu ovšem dodal, že Kameradenkreis odsuzuje všechny válečné zločiny, tedy i ty, které spáchali partyzáni na německých vojácích. Tím se opět přiblížil ke sporné tradiční argumentaci válečných veteránů, která stavěla utrpení německých vojáků na stejnou úroveň

102 Rafael Sala, „Gebirgsjäger gedenken der Kriegsopfer. Kameradenkreis will aussöhnen“, Garmisch-Partenkirchner Tagblatt, 18. srpna 2003. Srov. přetištěný novinový článek z Münchner Merkur, rozhovor s mluvčím Kameradenkreisu Behringerem a čtenářský dopis Rettelbacha v Die Gebirgstruppe 52, č. 4 (2003): 14-18.

103 Ernst G. Coqui, „Nachlese zur Brendtenfeier 2003. Eine Stellungnahme der Vorstandschaft“, Die Gebirgstruppe 52, č. 4 (2003): 3-5.

104 Hans Lindinger, „Brendtenfeier 2003“, Die Gebirgstruppe 52, č. 4 (2003): 6-8. Viz také „Wir dividieren die Toten nicht auseinander“, Die Gebirgstruppe 52, č. 4 (2003): 15-17. Harald Rettelbach, „Kein Dialog mit Demokratiefeinden“, Die Gebirgstruppe 52, č. 4 (2003): 17.

105 „Wir dividieren die Toten“, 16.

${ }^{106}$ Coqui, „Nachlese zur Brendtenfeier“, 4. Dokumentací byla myšlena svědectví válečných veteránů, která vycházela v časopisu Die Gebirgstruppe.

107 Coqui, „Nachlese zur Brendtenfeier“, 5. 
jako utrpení obětí. ${ }^{108} \mathrm{O}$ tom, že se celkový pohled členů Kameradenkreisu na válečné zločiny horských myslivců nezměnil, svědčilo i vyjádření Rettelbacha pro novináře, že Kefalonia a Kommeno byly absolutní výjimky. ${ }^{109}$ Coqui dále připomněl, že neexistuje kolektivní vina a o té individuální může rozhodnout jen soud nebo Bůh. Oni sami, jak vysvětlil mluvčí Behringer v rozhovoru pro média, nedělají mezi mrtvými „kamarády“ při vzpomínání na padlé žádné rozdíly.110

Odmítavé postoje vůči aktivistům a jejich požadavkům tehdejších představitelů Kameradenkreisu plynule navazovaly na způsob, kterým na stejná či podobná obvinění a protesty reagovali jejich předchůdci v dobách studené války. Zároveň je ale třeba zmínit netradiční iniciativu představenstva spolku, které se v té době již zcela skládalo z př́slušníků poválečné generace. Několik týdnů po setkání na Hohe Brendten odjel předseda Coqui v doprovodu dvou členů představenstva spolku do Kommena na oficiální připomenutí 60 . výročí od tragické události. ${ }^{111}$ Předseda to ve své zprávě z cesty zveřejněné v časopise Die Gebirgstruppe vysvětlil tím, že Kameradenkreis musí důrazněji než dřív ukázat dovnitř i navenek, jak usiluje o smíření s bývalými nepřáteli, podporuje vědecké zpracování zločinů a truchlí za „nevinné oběti na všech stranách“. Jen pak si totiž „kamarádi“ mohou připomínat „nesporně velké výkony německých horských myslivcü“ za druhé světové války. ${ }^{112}$

Coqui tím naplnil svou vlastní výzvu $\mathrm{k}$ toleranci jiných názorů a přesvědčení, čímž evidentně narážel na požadavky protestujících k důstojnému vzpomínání na civilní oběti masakrů. Udělal to ovšem způsobem, který odpovídal dosavadní činnosti členů Kameradenkreisu (např́ílad v rámci IFMS), protože jak Coqui dodal, uprímné připomínání padlých a mrtvých obětí války se nedá vynutit nebo nařídit. ${ }^{113}$ Vzhledem k tomu, že do té doby si představitelé Kameradenkreisu na svých setkáních, pokud vůbec, připomínali civilní oběti války jen v rámci abstraktního termínu „oběti diktatury a teroru“, který připojili ke vzpomínce na padlé „kamarády“, válečné protivníky a mrtvé vojáky Bundeswehru, ${ }^{114}$ představovala Coquiho cesta do Kommena v létě 2003 významný pokus o inovaci dosavadní spolkové

108 Více viz např. Kühne, „Zwischen Vernichtungskrieg und Freizeitgesellschaft“, 100-101.

109 Rafael Sala, „Gebirgsjäger gedenken der Kriegsopfer. Kameradenkreis will aussöhnen“, Garmisch-Partenkirchner Tagblatt, 18. srpna 2003.

110 „Wir dividieren die Toten“, 17.

111 Cestu zorganizoval a účast předsedy Coquiho a jeho místopředsedy Hanse Petera Mayera na slavnostním pietním aktu v Kommenu domluvil H. F. Meyer, který byl v té době členem Kameradenkreisu. Cestu do Kommena zmiňuje v již citované práci Meyer, Blutiges Edelweiß, 680.

112 Ernst G. Coqui, „Eine heiße Reise in eine bedrückende Vergangenheit“, Die Gebirgstruppe 52, č. 5 (2003): 6-9.

113 Coqui, „Nachlese zur Brendtenfeier“, 5.

114 Ibid., 15. 
praxe připomínání válečných událostí. Historici pracovní skupiny Napadnutelná péče o tradice a mluvčí VVN-BdA toto gesto nicméně zhodnotili jako úhybný manévr, snahu umlčet kritiku a odvrátit pozornost od dalších zločinů, ${ }^{115}$ př́padně jako promarněnou př́ležitost pokusit se o skutečné smíření tváří tvář s př̌živšími a pamětníky, kteří přicestovali do Mittenwaldu. ${ }^{116}$

Na rozhodnutí organizátorů kampaně uspořádat protesty v roce 2004 to v každém př́padě nemělo žádný vliv. Program byl jako $\mathrm{v}$ předchozím roce rozložen do dvou dnů. V sobotu se konaly přednášky a diskuse s pamětníky, další happeningy, koncert, pochody městem, rozdávání letáků a informačních novin. Aktivisté v nich kritizovali „uctívání vrahư“, podporovali finanční odškodnění pro řecké oběti masakrů a požadovali stíhání odpovědných i za méně známé zločiny, než byly ty spáchané v Kommenu a na Kefalonii. Část demonstrujících také kritizovala účast Bundeswehru v zahraničních misích a požadovala jeho okamžité rozpuštění. ${ }^{117} \mathrm{~V}$ neděli se konaly protesty v blízkosti Hohe Brendten ve snaze narušit klidný průběh veteránského setkání. Stejně jako v předchozím roce znemožnila policie aktivistům demonstrovat v př́mé blízkosti pomníku. Do kontaktu s veterány se tak mohli dostat jen během blokády př́stupových cest. Policie zadržela několik protestujících i přihlížejících, ${ }^{118} \mathrm{k}$ násilným střetům mezi demonstrujícími a místními, veterány, či policií však tehdy ani v následujících letech nedošlo. ${ }^{119}$

115 Klein, Mentner a Stracke, „Mörder unterm Edelweiß“, 14-18.

116 Ulrich Sander, „Leserbrief an das Garmisch-Partenkirchener Tagblatt. ,Wann wird diese Haltung, die dahinter steckt, endlich diskutiert und überwunden?“", Vereinigung der Verfolgten des Naziregimes - Bund der Antifaschistinnen und Antifaschisten, 21. srpna 2003, http://www.nrw.vvn-bda .de/texte/leserbrief_gap.htm.

117 Gronau, Auf blinde Flecken zeigen, 82-83.

118 „Langer Marsch durch die Vergangenheit. Zahlreiche Festnahmen bei Demonstrationszug der Brendtengegner durch Mittenwald“, Garmisch-Partenkirchner Tageblatt, 1. června 2004. Přepis tohoto a výběr dalších článků týkající se kampaně v letech 2002 a 2005 na stránkách pracovní skupiny Napadnutelná péče o tradice: „Widerspruch, Protest und Reaktion zum Edelweiss“, nadir, nedatováno, http://nadir.org/nadir/kampagnen/mittenwald/2005/bro/Widerspruch -Protest-und-Reaktion-zum-Edelweiss.html.

119 To ovšem neznamenalo, že policejní ozbrojené složky nebyly napadány slovně. Rovněž se mnozí protestující bránili pokusům o zadržení. Na druhou stranu protestující čelili v některých př́padech až př́liš restriktivním opatřením hraničících se šikanou ze strany policie v rámci prevence střetu demonstrantů s účastníky vzpomínkové slavnosti, což potvrdila jak veřejně prospěšná organizace pro lidská práva Grundrechtekomitee, tak i výrok soudu v př́ípadu M. Mohra. Viz Dirk Walter, „Gebirgsjäger: Gegner gewinnt vor Gericht", Garmisch-Partenkirchner Tagblatt, 13. května 2012, http://www.merkur-online.de/lokales/garmisch-partenkirchen/mittenwald /gebirgsjaeger-gegner-gewinnt-gericht-2315466.html. Zpráva viz „Präventiv-willkürlich eingehegtes Demonstrationsrecht auf bayrische Art“, Grundrechtekommitee, 15. května 2005, http:// www.grundrechtekomitee.de/node/250. 
Je zřejmé, že v reakci na neústupnost protestujících v roce 2004 upevnil i Kameradenkreis svůj postoj vůči nim založený na svých dosavadních premisách. $\mathrm{Na}$ jedné straně nadále považovali jeho představitelé dialog $s$ demonstranty za nemožný a nežádoucí, protože jejich skutečným cílem mělo být zrušení Bundeswehru a změna politického systému v ortodoxní komunismus. ${ }^{120} \mathrm{O}$ připravenosti demonstrantů k násilí mělo svědčit opakované pomalování pomníku provokativními hesly. Předsednictvo Kameradenkreisu spatřovalo jako svou povinnost bránit „obranyschopnou demokracii“, pročež vyzvalo Bundeswehr, politiky, obec i tisk k pevnému semknutí kolem spolku a obraně setkání na Hohe Brendten. ${ }^{121}$

Vzpomínková slavnost byla členy Kameradenkreisu naproti tomu prezentována jako místo, kam přicházejí němečtí, rakouští a italští „kamarádi“ $z$ vděčnosti ke svým padlým "kamarádům“ a předchůdcům. ${ }^{122} \mathrm{~V}$ duchu křestanství a humanity zde společně s delegacemi zahraničních veteránů vzpomínají i na své bývalé nepřátele. ${ }^{123}$ Hohe Brendten je proto symbolem smíření a spolupráce mezi národy. ${ }^{124}$ Podobně jako v předchozím roce ujistil Coqui ve svém projevu na Hohe Brendten, že Kameradenkreis si je vědom jak velkých úspěchů horských myslivců za druhé světové války, tak i jejich válečných zločinů. ${ }^{125} \mathrm{O}$ minulosti nesmějí existovat tabu, ale zároveň jak dodal, je třeba vyvracet nepravdu a diferencovat mezi těmi, kdo se provinili, a těmi, kdo byli „z přesvědčení, že jednají podle práva, hanebně zneužiti“. ${ }^{126} \mathrm{~V}$ rámci polní mše za mrtvé byly vzpomenuty i všechny oběti války, teroru a násilí.

$\mathrm{Na}$ Coquiho snahy klást $\mathrm{v}$ rámci péče o tradice horských myslivců větší, byt’ obecný a k ničemu nezavazující důraz na uznání zločinů horských myslivců a připomínání si jejich obětí v rámci oběti teroru a násilí navázal v roce 2005 nový předseda Manfred Benkel. Ve svém projevu na Hohe Brendten poprosil oběti jménem všech členů Kameradenkreisu za odpuštění „tam, kde jednotlivec selhal“. ${ }^{127}$ Komu

120 Christof Schnürer, „Kein Dialog und keine Entschuldigung. Kameradenkreis behält Linie bei“, Garmisch-Partenkirchner Tageblatt, 20. května 2004; „Warum wir Ziel linksextremer Umtriebe sind. Antifaschismus und Demokratie“, Die Gebirgstruppe 53, č. 4 (2004): 13-15.

121 „Warum wir Ziel linksextremer Umtriebe sind. Antifaschismus und Demokratie“, Die Gebirgstruppe 53, č. 4 (2004): 13-15.

122 „Gedenkfeier der Gebirgstruppe am Hohen Brendten 2004“, Die Gebirgstruppe 53, č. 4 (2004): 4-6, zde 5.

${ }^{123}$ Hans Lindinger, „Das Pfingsttreffen in Mittenwald“, Die Gebirgstruppe 53, č. 4 (2004): 6-7.

124 Nadine Nöhmaier, „Ein Gebirgsjäger für das ganze Leben“, Münchner Merkur, 7. června 2004, http://www.merkur-online.de/lokales/regionen/gebirgsjaeger-ganze-leben-201996.html.

125 „Gedenkfeier der Gebirgstruppe am Hohen Brendten 2004“, Die Gebirgstruppe 53, č. 4 (2004): 5.

126 Ibid.

127 „Ansprache des Präsidenten bei der 48. Gedenkfeier am Hohen Brendten“, Die Gebirgstruppe 54, č. 3 (2005): 2-4. 
bude prokázána vina, pokračoval Benkel, musí se za ni zodpovídat, v poslední instanci před Bohem. Nepochybně v souvislosti s rétorikou a hesly kampaně, která Kameradenkreis označovala jako „svépomocnou skupinu pro válečné zločince“ (Selbsthilfegruppe für Kriegsverbrecher), ${ }^{128}$ neopomněl zdůraznit, že existuje jen individuální vina a že žádný člen Kameradenkreisu do té doby nebyl odsouzen. Celkově se Benkelova řeč nesla ve znamení 60 . výročí od konce války s patrnými odkazy na probíhající protesty: Cesta $\mathrm{k}$ míru a svobodě začíná připomenutím si vojáků, kterým jejich mládí nedovolilo prohlédnout systém, že je využívá. Jejich smrt nabádá $\mathrm{k}$ bdělosti a připravenosti bránit demokratický stát před těmi, kdo chtějí změnit jeho politický systém. Vzpomínka, varování a smírení, jehož viditelným projevem bylo IFMS, tak byly podle Benkela tři nutné kroky k tomu, jak zabránit nové válce. ${ }^{129}$

Projev předsedy Kameradenkreisu odrážel jak odhodlání neustoupit protestujícím a pečovat dál o tradice horských myslivců vlastním způsobem, tak snahu udělat dobrý dojem na veřejnost a v neposlední řadě na místní radnici. Už počátkem roku 2005 navrhli zastupitelé města kvưli obavám z negativního vlivu protestní kampaně na cestovní ruch během letnicových svátků Kameradenkreisu, aby své setkání na Hohe Brendten přesunul na jiný termín. ${ }^{130}$ Velký podíl na negativním zobrazení péče o tradice horských myslivců měl podle Kameradenkreisu tisk, který referuje neobjektivně a jednostranně dává prostor pouze „nactiutrhačné kampani“" radikálních antifašistů a komunistů. ${ }^{131}$

V roce 2006 se setkání na Hohe Brendten poprvé konalo již před letnicovými svátky, což organizátoři protestů prohlásili za svůj úspěch formou kampaňového hesla "napadená péče o tradice“ (Angegriffene Traditionspflege). ${ }^{132}$ Benkel zde promluvil v podobném duchu jako předchozí rok a opět neprrímo zareagoval na požadavky protestujících, když zdůraznil, že Kameradenkreis usiluje o smíření a porozumění mezi národy nikoliv tlakem a konfrontací, ale prostřednictvím vzpomínání na padlé na všech stranách a na všechny oběti diktatur a teroru. ${ }^{133}$

128 „Mittenwald 2005 - Endlich Weg damit“, nadir, nedatováno, http://nadir.org/nadir/kampagnen /mittenwald/2005/aufruf2005.html.

129 „Gedenkfeier der Gebirgstruppe am Hohen Brendten 2004“, Die Gebirgstruppe 53, č. 4 (2004): 5.

130 Christof Schnürer, „Kameradenkreis von Gemeinde enttäuscht“, Garmisch-Partenkirchner Tagblatt, 15. března 2005, http://www.merkur-online.de/lokales/regionen/kameradenkreis-gemeinde-enttaeuscht-251769.html.

${ }^{131}$ Hans Lindinger, „Ein Appell an die Medien. Gedanken eines besorgten Demokraten anlässlich der Brendtenfeier 2005“, Die Gebirgstruppe 54, č. 3 (2005): 11-12.

132 Gronau, Auf blinde Flecken zeigen, 86.

133 Ansprache des Präsidenten des Kameradenkreises der Gebirgstruppe, Oberst a.D. Manfred Benkel, Die Gebirgstruppe 55, č. 4 (2006): 4-5. 
Př́kladem toho měla být cesta tříčlenné delegace Kameradenkreisu do řecké obce Paramythia, kde horští myslivci v roce 1943 zastřelili 49 mužských obyvatel v odvetě za smrt pěti vojáků. Místní kulturní spolek pozval zástupce Kameradenkreisu, aby si jejich smrt společně připomněli během oslav Dne Evropy, a přispěli tak $\mathrm{k}$ německo-řeckému smíření. ${ }^{134}$

V roce 2007 se setkání na Hohe Brendten konalo již natrvalo v termínu před letnicemi. Díky tomu, že se slavilo výročí padesáti let od vztyčení pomníku, byla účast členů i nečlenů veteránského spolku oproti předchozím letům výrazně vyšší. ${ }^{135}$ Mezi 2000 účastníky byla prítomna řada delegací zahraničních veteránských spolku a obzvláště vítaná delegace ředitele kulturního spolku a místostarostů města Paramythia. ${ }^{136}$ Projevy předsedy Benkela na Hohe Brendten se v roce 2007 a v dalších dvou letech lišily jen v detailech. Nechybělo v nich vzpomínání na padlé všech válečných stran a vojáků Bundeswehru, jakož i oběti teroru a diktatur, ani přiznání, že i jednotky horských myslivců wehrmachtu se za války dopustily „chyb“. ${ }^{137}$ Ze vzpomínání na tyto činy a oběti vyplývaly pro členy Kameradenkreisu odpovědnost a závazek do budoucna se poučit $\mathrm{z}$ minulosti a usilovat o smíření a porozumění mezi národy. ${ }^{138}$ Vedle toho se Kameradenkreis snažil bránit „jednostrannému“ a negativnímu obrazu v médiích články ve svém periodiku. ${ }^{139}$ Více se mu v letech 2008 až 2009 dařilo v soudních sporech se spolkovým mluvčím VVN-BdA kvưli urážkám na cti. ${ }^{140}$

V roce 2008 se část protestujících rozhodla reagovat na slábnoucí schopnost mobilizovat veřejnost $\mathrm{k}$ účasti na společné manifestaci s pamětníky a přeživšími válečných událostí v Mittenwaldu tím, ${ }^{141}$ že se pokusila př́mo narušit konání

134 Viz také Franz Penzkofer, „Gemeinsam am Haus Europa bauen. Kameradenkreis der Gebirgstruppe zum Europatag in Griechenland“, Die Gebirgstruppe 55, č. 4 (2006): 13-14.

135 „Das Gedenken der Toten ist Verpflichtung zum Frieden - 50 Jahre Ehrenmal am Hohen Brendten wird mit Freunden aus Griechenland gefeiert", Die Gebirgstruppe 56, č. 3 (2007): 3-4.

136 Ředitel kulturního spolku pronesl krátkou řeč. Viz „Grußworte - Dimitrios Tsarkovistas, Präsident des Kulturvereins FOP“, Die Gebirgstruppe 56, č. 3 (2007): 4-5.

137 Gebirgsjäger-Treffen: Kameradenkreis-Präsident schlägt selbstkritische Töne an“, Garmisch-Partenkirchner Tagblatt, 4. května 2008, http://www.merkur-online.de/lokales/garmisch-partenkirchen /landkreis/gebirgsjaegertreffen-kameradenkreispraesident-schlaegt-selbstkritische-toene-284687. html.

138 „Gedenkfeier 2008 auf dem Hohen Brendten“, Die Gebirgstruppe 57, č. 3 (2008): 4-5.

139 Viz např. Franz Penzkofer, „Unter die Lupe genommen“, Die Gebirgstruppe 55, č. 5 (2006): 33.

140 „Mitteilung der Vorstandschaft“, Die Gebirgstruppe 58, č. 1 (2009): 6-7; „Informationen für unsere Mitglieder: Prozess gegen U. Sander, VVN-BdA, erfolgreich abgeschlossen“, Die Gebirgstruppe 58, č. 2 (2009): 30.

141 V letech 2003 až 2007 se kampaně účastnilo mezi 200 až 600 protestujících, v letech 2008 až 2009 kolem 150 protestujících. Viz Gronau, Auf blinde Flecken zeigen, 94. 
slavnosti na Hohe Brendten. ${ }^{142}$ Po této neúspěšné akci se původní organizátoři kampaně rozhodli protesty a manifestace na letnice roku 2009 ukončit. ${ }^{143}$ Vyvrcholením jednodenní demonstrace bylo odhalení pomníku věnovaného obětem válečných masakrů horských myslivců na místě jejího konání - před mittenwaldským nádražím. Na rozdíl od symbolických pomníků z papíru, či lehko odstranitelného materiálu, které protestující instalovali v ulicích Mittenwaldu v předchozích letech, byl tento monument vyroben ze železa a kamení a jak z funkčního, tak estetického hlediska splňoval kritéria pomníku. Město jej však s poukazem na bezpečnostní předpisy a chybějící schvalovací proces nechalo po několika dnech odstranit. ${ }^{144}$ Až pod tlakem médií zahájila mittenwaldská radnice jednání s pracovní skupinou Napadnutelná péče o tradice a dohodla se s ní na umístění pomníku př̀ed mittenwaldskou základní a střední školou. ${ }^{145}$

V březnu 2010 byl tento pomník slavnostně vysvěcen za př́tomnosti městské honorace i zástupců Kameradenkreisu. Během projevu představitele pracovní skupiny Napadnutelná péče o tradice, který nijak neslevil z bojovné a konfrontační rétoriky předchozích let, opustili prredseda a místopředseda veteránského spolku sál a vrátili se až na samotný akt vysvěcení. ${ }^{146}$ Vyjádřili tak respekt k obětem, nikoliv k zástupci protestujících. Svůj postoj k přijetí tohoto pomníku však předsednictvo Kameradenkreisu nikdy explicitně neformulovalo a ani v rámci setkání na Hohe Brendten na něj předseda spolku nikdy nepoukázal. Lze předpokládat, že se mnoho členů především ze starší generace s jeho existencí nesmírílo. V časopise Die Gebirgstruppe k tomu vyšel pouze jeden př́spěvek. V něm se řadový člen Kameradenkreisu rozhořčuje nad podporou, kterou druhá největší odborářská organizace v Německu Verdi poskytla demonstraci, během níž došlo k ilegální instalaci pomníku obětem masakrů. ${ }^{147}$ Ten podle něj nebyl ničím jiným než „pro-

142 Ibid., 90.

143 „,Kein Vergeben, kein Vergessen`: Letzte Pfingstdemo in Mittenwald“, Garmisch-Partenkirchner Tagblatt, 26. května 2009, http://www.merkur-online.de/lokales/garmisch-partenkirchen/landkreis /kein-vergeben-kein-vergessen-letzte-pfingstdemo-mittenwald-318966.html. Srov. AK Angreifbare Traditionspflege, „Kameradenkreis der Gebirgstruppe“, 159.

144 Joachim Tornau, „Gabelstabler gegen Gedenken“, Frankfurter Rundschau, 12. června 2009, http:// www.fr-online.de/politik/alpenkurort-mittenwald-gabelstabler-gegen-gedenken,1472596,3368824. html.

145 „Gemeinde nimmt, Stein des Anstoßes' an“, Garmisch-Partenkirchner Tagblatt, 15. listopadu 2009, http://www.merkur-online.de/lokales/garmisch-partenkirchen/landkreis/gemeinde-nimmt-stein -anstosses-529690.html.

146 „Feierstunde mit Störfeuern“, Garmisch-Partenkirchner Tagblatt, 21. března 2010, http://www.merkur -online.de/lokales/garmisch-partenkirchen/landkreis/feierstunde-stoerfeuern-683371.html.

147 „Wie konsequent sind wir eigentlich? Ein Kamerad kündigte seine Mitgliedschaft bei VERDI“, Die Gebirgstruppe 58, č. 6 (2009): 58-59. 
vokací vůči horským myslivcům, obyvatelům Mittenwaldu a všem mírumilovným občanům“. ${ }^{148}$ Coby konsekventní krok oznámil své rozhodnutí z odborů vystoupit.

Třebaže se část aktivistů nechtěla smírit s koncem kampaně a i na rok 2010 vyzvala $\mathrm{k}$ účasti na protestech, ${ }^{149} \mathrm{k}$ jejich dalšímu pokračování v Mittenwaldu už nedošlo. ${ }^{150}$ Vzpomínkové slavnosti na Hohe Brendten v následujících letech měly i přes to skromnější charakter, poznamenaný trvale menším počtem účastníků (500 až 700) a neúčastí čestných hostů v osobě velitelů horské brigády Bundeswehru. V projevech, které Die Gebirgstruppe přestala uveřejňovat v plném znění, se již předseda Kameradenkreisu explicitně nezmiňoval o „pochybeni“ vojáků wehrmachtu, zůstala $\mathrm{v}$ nich nicméně formulace o připomínání si civilních obětí násilí a diktatur. ${ }^{151}$

\section{Závěr}

Způsob vedení kampaně a její požadavky nedávaly Kamaradenkreisu velký manévrovací prostor. Pokud by jim předsednictvo chtělo vyjít vstříc, mělo na výběr mezi radikálním přehodnocením většiny svých dosavadních cílů, aktivit a tradic, nebo úplným stažením $\mathrm{z}$ veřejného života, přerušením kontaktů s Bundeswehrem, zrušením vzpomínkových slavností a odstraněním pomníku na Hohe Brendten i všech ostatních pomníků, případně zrušením spolku jako takového. $\mathrm{V}$ každém př́padě by to znamenalo silné zpochybnění, pokud ne prrímo zánik vlastní padesát let budované identity spolku. Předsednictvo Kameradenkreisu si takovou možnost evidentně nikdy nepřipustilo. Naopak rychle přešlo do ofenzivy tím, že kritiku a požadavky protestujících v rámci svých omezených možností veřejně diskreditovalo. Kvůli zvýšené pozornosti médií byli ale oba předsedové spolku ochotni provést $\mathrm{v}$ dosavadní praxi určité změny. Tematizovali některé

148 Ibid.

149 Výzva k protestům byla zveřejněna na nových stránkách personálně obměněné pracovní skupiny Napadnutelná péče o tradice (AK Angreifbare Traditionspflege/Neue Folge): „Auf zur Befreiungsfeier nach Mittenwald“, Berg Frei Mittenwald!, http://mittenwald.blogsport.eu/2010/03/30 /auf-zur-befreiungsfeier-nach-mittenwald/.

150 Organizátoři pro nedostatek peněz a zájmu akci zrušili. Viz Jean Amery, „Mit Bedauern...., Berg Frei Mittenwald!, http://mittenwald.blogsport.eu/2010/05/05/mit-bedauern\%E2\%80\%A6/. Srov. „Gedenkfeier ohne Störfeuer“, Garmisch-Partenkirchner Tagblatt, 9. května 2010, http://www.merkur-online .de/lokales/garmisch-partenkirchen/landkreis/gedenkfeier-ohne-stoerfeuer-754776.html.

151 Viz „Brendtenfeier 2010“, Die Gebirgstruppe 59, č. 3 (2010): 9; Rudolf Reiter, „Brendtenfeier 2011“, Die Gebirgstruppe 60, č. 3 (2011): 3-5; Hans Peter Mayer, „Gedenkfeier 2012 auf dem Hohen Brendten“, Die Gebirgstruppe 61, č. 3 (2012): 3-6; „Brendtenfeier 2013 und 35 Jahre Tragtierdenkmal, Auszug aus der Begrüßung durch den Präsidenten bei der Brendtenfeier 2013“, Die Gebirgstruppe 62, č. 3 (2013): 3-8, zde 9. 
dlouho zamlčované otázky, kladli větší důraz na civilní oběti a iniciovali nové aktivity na poli usmiřování mezi národy. Zároveň však dbali o to, aby tyto kroky byly v souladu s původními cíli spolku a tradiční interpretací role horských jednotek za druhé světové války, která zlehčovala nebo zamlčovala jejich účast na většině známých válečných zločinů.

Skutečnost, že výraznější změny představovaly více méně jednorázové pokusy nepřesahující svým dopadem dobu kampaně, svědčilo o tom, že ani u většiny „kamarádü“ $\mathrm{k}$ žádnému radikálnímu obratu v myšlení nedošlo. Předseda Coqui sice na Hohe Brendten odsoudil události na Kefalonii a v Kommenu, to ale neznamenalo, že by se s tímto pohledem ztotožnili i všichni členové. ${ }^{152}$ Navíc se to $\mathrm{v}$ této formě stalo pouze jednou na začátku kampaně, tedy v době, kdy oba masakry byly silně medializovány a všeobecně platily za nepopiratelné zločiny wehrmachtu. Později už Coqui i Benkel hovořili pouze obecně o válečných zločinech, kterých se dopustili i vojáci horských jednotek a kterých si je Kameradenkreis vědom, př́padně jich lituje, konkrétně je ale nejmenovali. I díky tomu mohly válečné zločiny na Kefalonii a v Kommenu vypadat jako absolutní výjimky, za které je většina „kamarádü“ pokládala, pokud si ovšem dál nemysleli, že jde o vymyšlená nařčení.

Je př́iznačné, že zástupci Kameradenkreisu zřídka používali pojmu „válečný zločin“. Většinou ho nahradili méně právnickým termínem jako „pochybení, „bezpráví, „přešlap“, př́padně neutrálním popisem události válečnou terminologií jako v prŕípadě Paramythia, o které Benkel hovořil jako o zastřelení civilních rukojmí v reakci na zabití pěti německých vojáků partyzány. Takto nazvané válečné zločiny působily méně zavrženíhodně a navíc nezakládaly bezprostřední důvod nazývat jejich pachatele „vrahy“ nebo „zločinci“, jako to dělali protestující v kampani. Představitelé Kameradenkreisu skoro nikdy nejmenovali konkrétní jednotky, v nichž se mělo vyskytovat několik jedinců, kteří zločiny spáchali. To nepochybně souviselo s požadavkem „kamarádư“ nikoho neobviňovat, dřive než bude zjištěna individuální vina konkrétního pachatele. Z hlediska práva šlo jistě o legitimní požadavek. Nicméně $\mathrm{k}$ tomu je třeba dodat, že velká většina členů Kameradenkreisu ve své dlouhé historii udělala minimum pro to, aby skuteční

152 V roce 2005 bylo ve zkrácené verzi znovu otištěno svědectví Wernera Funkeho, který reagoval na obvinění své osoby v rámci protestní kampaně z účasti na masovém stř́lení italských zajatců. Funke patřil k jednotce, která se podle dosavadních historických výzkumů nade vší pochybnost masových stř́lení účastnila. Přesto Funke zopakoval, že i když k „nějakému stř́ilení" asi došlo, on sám byl svědkem zastřelení pouze asi 30 Italů na vyšší příkaz, a ohradil se proti obvinění celé své jednotky. Viz Werner Funke, „Sind Zeitzeugen noch erwünscht? Ein Brief von jemand, der es wissen muss“, Die Gebirgstruppe 54, č. 3 (2005): 13-15. 
pachatelé byli obžalováni a usvědčeni. Naopak se před vyšetřovateli německé justice i norimberského tribunálu domlouvali a kryli navzájem, př́ípadně svalovali odpovědnost na již mrtvé důstojníky.

V konečném důsledku tak odmítnutí „paušalizace“ sloužilo jako výmluva, aby Kameradenkreis mohl zločiny odsoudit pouze verbálně a nemusel z toho vyvozovat žádné důsledky pro stávající či bývalé členy spolku v podobě vyloučení nebo veřejné distance od nich. Místo toho hájili předsedové i další členové spolku tradiční kult padlých všech bez výjimky. Odkazovali přitom na křestanské odpuštění, humanitu a v neposlední řadě na „kamarádství“ ve vojenském slova smyslu. Názorně to demonstrují slova Coquiho, který při setkání na Hohe Brendten v roce 2003 novinářům řekl, že si připomínají lidi, a ne jejich činy. ${ }^{153}$ Nacisticky smýšlející generál Dietl, který padl už za války, tak pro něj byl „v prvé řadě horský myslivec a voják“. ${ }^{154}$ Skutečnost, že byl dobrým nadř́zeným a „kamarády“ v boji nenechal na holičkách, tak rozhodovala o lidských kvalitách více než to, že jednal proti válečnému právu. To, že Kameradenkreis přes deklarované úmysly ve skutečnosti nehodlal zaujmout jasný postoj k válečným zločincům uvnitř svých řad, potvrzuje i fakt, že ani po pravomocném odsouzení Josefa Scheungrabera, bývalého horského myslivce a člena Kameradenkreisu, nenásledovalo žádné oficiální prohlášení, veřejné odsouzení jeho činu, ani lítost nad brutálně zabitými italskými civilisty. Sice už pak představitelé Kameradenkreisu přestali používat argument, že žádný člen Kameradenkreisu nebyl nikdy odsouzen, k tomu je ale třeba dodat, že to nebyla pravda ani prred rokem 2009. Někdejší čestný předseda Kameradenkreisu generál Lanz byl odsouzen americkým tribunálem v Norimberku v roce 1947 a poté, přestože se to uvnitř Kameradenkreisu tradovalo, nebyl nikdy zproštěn viny německým soudem. ${ }^{155}$

Stojí za pozornost, že předsednictvo Kameradenkreisu, které se v době kampaně již zcela skládalo ze střední generace bývalých vojáků Bundeswehru, která za

153 Nadine Nöhmaier, „Ein Gebirgsjäger für das ganze Leben“, Münchner Merkur, 7. června 2004, http://www.merkur-online.de/lokales/regionen/gebirgsjaeger-ganze-leben-201996.html.

154 Gronau, Auf blinde Flecken zeigen, 98.

155 Sám Lanz se odvolával na rozsudek italského vojenského soudu z roku 1960, který ho měl zprostit viny za masakr válečných zajatců na Kefalonii. Ve skutečnosti se jednalo o zastavení vyšetřování, vedeného vyšetřujícím soudcem bez jakékoliv možnosti kontaktu s německými podezřelými a svědky. Kromě toho Lanze nezbavoval odpovědnosti za zločiny na řeckých civilistech, za které byl také odsouzen Norimberským tribunálem. Viz Hubert Hipp, „Geschichte des Kameradenkreises der Gebirgstruppe“, Die Gebirgstruppe 50, Sonderheft (ř́ijen 2001): 12-28. Srov. Schminck-Gustavus, Kephalloniá, 164. Stojí za pozornost, že členové Kameradenkreisu uznávali rozsudky italského soudu, pouze když obviněného osvobozovaly. Soudní řízení s příslušníky horských myslivců za válečné zločiny, která v jejich nepřítomnosti probíhala v Itálii od konce 90. let, nebrali členové spolku včetně samotných odsouzených (např. Josef Scheungraber, Alfred Stork) vůbec na vědomí. 
války nebojovala, a nenesla si tedy z nacistického období žádnou zátěž, zůstávalo při interpretaci válečné minulosti horských myslivců přesto do značné míry věrno tradiční linii svých předchůdců. Pravděpodobně k tomu přispělo více faktorů. Tato generace chovala respekt ke svým někdejším nadřízeným $\mathrm{v}$ Bundeswehru $\mathrm{z}$ řad wehrmachtu, kteří je naučili řemeslu. ${ }^{156}$ Vážila si jejich charakterových vlastností na základě vlastní osobní zkušenosti a cenila si toho, co veteráni po válce prostřednictvím Kameradenkreisu vybudovali. ${ }^{157}$ Určitý vliv mohla mít obava mladších členů spolku z toho, že uznání všech zločinů horských divizí za druhé světové války by vedla k otřesu jejich vlastní identity a ztrátě společenské prestiže coby dědiců elitních horských jednotek wehrmachtu. ${ }^{158}$ Vzhledem k tomu, že pro svůj postoj nacházeli zastání $\mathrm{v}$ aktivních velitelích Bundeswehru i ve spolkovém ministerstvu obrany, ${ }^{159}$ nebyli nuceni zacházet dál, než co bylo o provinění vojáků wehrmachtu za druhé světové války řečeno $\mathrm{v}$ druhém výnosu o tradicích.

V každém prrípadě museli mladší členové spolku brát ohled na jeho dosud žijící veterány $\mathrm{z}$ generace zakladatelů spolku, kteř́ ještě v roce 2004 tvořili asi polovinu členů. ${ }^{160}$ Podle toho jak se její zástupci i po roce 2002 vyjadřovali v časopise Die Gebirgstruppe, zastávali ve své většině i nadále legendu o „čistém wehrmachtu“. Ve svých příspěvcích popírali zločinný charakter válečného tažení wehrmachtu nebo jej relativizovali poukazem na „válečné zločiny“ Spojenců. Za sebe i za padlé „kamarády" požadovali milost, odpuštění a tlustou čáru za minulostí. ${ }^{161}$ Vojáci wehrmachtu šli do boje s hlubokou vírou ve správnost svého jednání. ${ }^{162}$ Mrtví „kamarádi“ si proto zaslouží úctu a vděk, protože padli proto, aby oni sami mohli žít. Ti, kteří přežili válku i utrpení v zajateckých táborech, mají být respektováni za to, že položili materiální i duchovní základy demokratického právního státu, a tím dostatečně odčinili svá př́padná pochybení. ${ }^{163}$ Kromě toho př́islušníci válečné generace horských myslivců vyzdvihovali také své zásluhy na udržení míru a porozumění mezi národy svým dlouhodobým úsilím o usmíření s bývalými válečnými protivníky.

156 Viz výrok Rettelbacha v práci Joachim Tornau, „NS-Orden stören den soldatischen Schulterschluss in Mittenwald nicht", Frankfurter Rundschau, 21. května 2002.

157 Meyer, Blutiges Edelwei $\beta, 680$.

158 Viz Werner Funke, „Sind Zeitzeugen noch erwünscht? Ein Brief von jemand, der es wissen muss“, Die Gebirgstruppe 54, č. 3 (2005), 13-15.

159 „Stellungnahme zum Traditionsverständnis“, Die Gebirgstruppe 55, č. 3 (2006): 36.

160 Údaj převzatý z článku „Gedenkfeier der Gebirgstruppe am Hohen Brendten 2004“, Die Gebirgstruppe 53, č. 4 (2004): 4-6. O rok později hovořil prredseda už jen o třetině. Viz „Ansprache des Präsidenten bei der 48. Gedenkfeier am Hohen Brendten“, Die Gebirgstruppe, 54, č. 3 (2005): 4.

161 Gerhart Klamert, „Gedanken eines Zeitzeugen, der die Schrecken des Partisanenkrieges erleben mußte", Die Gebirgstruppe 52, č. 5 (2003): 20-21.

162 Ibid.

163 Gerhart Klamert, „To whom it may concern: nur Ballast?“, Die Gebirgstruppe 53, č. 3 (2004): 4-5. 
Tváŕí tvář nepř́ijemné protestní kampani se předsednictvo rozhodlo pro zachování stávající praxe připomínání padlých, ale paralelně $\mathrm{k}$ tomu se přihlásilo $\mathrm{k}$ podpoře hlubšího vědeckého zpracování válečné minulosti horských myslivců a k usmiřování s civilními obětmi války nad rámec dosavadní spolupráce v IFMS. Třebaže Kameradenkreis skutečně dal podnět a poskytl dokumenty svého archivu k napsání minimálně jedné diplomové práce, praktické důsledky tohoto kroku se nijak neprojevily na hodnocení válečného zločinu na Kefalonii ani uvnitř spolku, ani na veřejnosti. ${ }^{164} \mathrm{~V}$ př́padě usmiřování s civilními obětmi se předsevzetí předsedů Coquiho a Benkela podařilo naplnit jen částečně.

Cesta do Kommena, kde se delegace Kameradenkreisu účastnila vzpomínkového aktu více méně inkognito a dostalo se jí zdvořilého přijetí od starosty spíše soukromého rázu, se pro budoucí aktivity Kameradenkreisu v tomto směru ukázala jako slepá ulička. ${ }^{165}$ Hlavním důvodem neúspěchu bylo, že Kameradenkreis neusiloval o usmíření na základě přiznání viny, pokání a žádosti o odpuštění př́ímo obětí či jejich pozůstalých, ale o usmíření „vlastním způsobem“, tedy podle modelu, který fungoval v rámci IFMS. To ve skutečnosti znamenalo reciproční zapomenutí na bezpráví, kterého se měly dopustit obě strany, projev úcty $\mathrm{k}$ mrtvým a padlým bez rozdílu mezi pachateli a obětmi na obou stranách a vzájemné ujištění o odhodlání zabránit opakování války. Ten stejný model uplatnila delegace předsedy Benkela i při cestě do Paramythie a přijetí řecké delegace na Hohe Brendten. Na rozdíl od situace $\mathrm{v}$ Kommenu to bylo možné proto, že navázání kontaktu s Kameradenkreisem za účelem upevnění řecko-německé spolupráce a posílení míru inicioval místní kulturní spolek, nikoliv zástupce obětí a pozůstalých válečných zločinů v Řecku.

Nutno dodat, že s tímto způsobem usmiřování s bývalými válečnými nepřáteli měli „kamarádi“ zkušenost již před návštěvou Paramythie. V roce 2003 a znovu 2010 si nad pomníkem partyzány zabitých horských myslivců v krétském Kandanosu připomněli spolu se starostou obce i řecké oběti následných odvetných opatření. ${ }^{166}$ Přitom však žádný člen Kameradenkreisu dosud neuznal fakt, že na Krétě došlo $\mathrm{k}$ hrubému porušení válečného práva, na kterém se podíleli i bývalí horští

${ }^{164}$ Christoph Huber, „Eine Analyse der Kriegsverbrechen des XXII. Gebirgsarmeekorps auf der Insel Kephalonia im September 1943“ (Diplomarbeit, Universität der Bundeswehr München. Fakultät für Staats- und Sozialwissenschaften, 2001). Z důvodu ochrany osobních údajů je práce prístupna v univerzitní knihovně jen se zvláštním povolením.

165 Viz Klein, Mentner, Stracke, „Die Mörder unterm Edelweiß“, 17.

166 „Manfred Rehm: Versöhnungsreise nach Kreta“, Die Gebirgstruppe 52, č. 6 (2003): 70-73; "Gebirgsjägerreise Kreta 2010, Militärhistorische Exkursion“, Die Gebirgstruppe 59, č. 4 (2010): $10-14$. 
myslivci. ${ }^{167}$ I proto se od roku 2011 konají menší protesty autonomního uskupení RABATZ a dalších antifašistických aktivistů v Bad Reichenhallu proti ceremonii spojené s uctěním památky horských myslivců padlých při dobývání Kréty. ${ }^{168}$

Celkový postoj Kameradenkreisu k mittenwaldským protestům se dá charakterizovat jako vyčkávání, až se aktivisté unaví. V každém případě se usilovně snažili neztratit tvář tím, že by podlehli „vydírání levicových radikálü“. Ústupky Kameradenkreisu, které protestující prohlašovali za svá dílčí vítězství, předsednictvo interně podávalo jako vlastní rozhodnutí, at už se jednalo o rozpuštění jedné z podřízených organizací, ${ }^{169}$ nebo posunutí termínu setkání na Hohe Brendten. ${ }^{170}$ Nepřehlédnutelná je také podobnost obranné strategie Kameradenkreisu s tou, kterou používal vůči protestům a „nactiutrhačným“ kampaním v době studené války: diskreditace protestujících a jejich požadavků poukazem na jejich světonázor neslučitelný s demokratickým pořádkem. Jakákoliv změna v praxi vzpomínání na válku, která by byla v souladu s požadavky protestujících, by tak podle Benkela nepředstavovala krok k vyrovnání se s vlastní minulostí, ale „podlehnutí ideologickým zaslepencům, kteří náš [německý] lid už jednou přivedli do neštěstí'. ${ }^{171}$

Další vývoj Kameradenkreisu a jeho péče o tradice ukáže budoucnost. Ubývá aktivních horských myslivců a tím i potenciálních členů, proto je pravděpodobná spíše pokračující marginalizace spolku, až jeho postupný zánik. Nejmladší generace horských myslivců nejenže necítí vinu za zločiny wehrmachtu, ale již ani není spjata osobními vazbami s válečnou generací. Lze tedy očekávat, že i v budoucnosti budou vojáci Bundeswehru v určité míře $\mathrm{z}$ úcty $\mathrm{k}$ tradicím udržovat některé

167 Během invaze na Krétu v květnu 1941 přišla německá armáda v boji s britskou armádou o více než 4000 výsadkářů a horských myslivců. Do obrany ostrova se zapojili i krétští civilisté a partyzáni a mnohdy brutálním způsobem německé vojáky zabíjeli. Bezprostředně po obsazení na základě spontánních aktů pomsty a v následujících měsících na základě odvetného opatření velícího generála zastřelili př́slušníci horských myslivců a výsadkářů asi 2000 civilistů bez ohledu na jejich skutečné individuální provinění. Srov. Stracke, „Mörder unterm Edelweiß“, 34-40. Srov. „Stellungnahme zum Partisanenkrieg auf Kreta“, Die Gebirgstruppe 37, č. 1 (1988): 20-21. Klaus Hammel, „Vor 60 Jahren - die Eroberung der Insel Kreta", Die Gebirgstruppe 50, č. 3 (2001): 8-13.

168 „Antifaschistische Demo in Bad Reichenhall“, Indymedia, 7. května 2012, http://de.indymedia .org/2012/05/329636.shtml?print=on. Srov. „Die Kulturhöhe eines Volkes erkennt man daran, wie es mit seinen Gefallenen umgeht, Kretagedenkfeier am Mahnmal an der Kretabrücke“, Die Gebirgstruppe 60, č. 3 (2011): 22-24.

169 Předsednictvo se mělo až na základě televizní reportáže dozvědět, že 18. policejní regiment byl od roku 1943 podřízen SS. Viz „Mitteilung des Vorstands. Auszug aus dem Protokoll der außerordentlichen Vorstandssitzung vom 31. května 2005“, Die Gebirgstruppe 54, č. 3 (2005): 49-50.

170 Zvláště aktivní vojáci mezi členy spolku měli dlouhodobě žádat o posunutí termínu, aby sváteční dny mohli trávit s rodinou. Viz Manfred Benkel, „Terminänderung - Brendtenfeier“, Die Gebirgstruppe 57, č. 1 (2008): 3.

171 Manfred Benkel, „Liebe Kameradinnen, liebe Kameraden!“, Die Gebirgstruppe 56, č. 2 (2007): 2. 
rituály a étos „kamarádstvi“‘, zároveň však bude růst význam více než padesátileté tradice Bundeswehru včetně zkušeností vojáků, kteří se účastnili zahraničních misí z posledních dvou dekád. Svědčí o tom mimo jiné i skladba článků v časopise Die Gebirgstruppe z posledních let, na které je patrné, že současné členy Kameradenkreisu zajímají současné vojenské a sportovní aktivity horských myslivců více než historie druhé světové války očima jejích účastníků. 